\title{
Milankovitch climate forcing in the tropics of Pangaea during the Late Triassic
}

\author{
Paul E. Olsen, Dennis V. Kent \\ Lamont-Doherty Earth Observatory of Columbia University, Palisades, NY 19068, USA
}

Received 12 January 1995; revised and accepted 23 June 1995

\begin{abstract}
During the Late Triassic, the Newark rift basin of Eastern North America was in the interior of tropical $\left(2.5-9.5^{\circ} \mathrm{N}\right)$ Pangaea. Strikingly cyclical lacustrine rocks comprise most of the $6770 \mathrm{~m}$ of continuous core recovered from this basin by the Newark Basin Coring Project. Six of the seven drill cores (each from 800 to $1300 \mathrm{~m}$ long) from this project are used to construct a composite lake-level curve that provides a much needed record of long term variations in continental tropical climate. The correlations on which the composite section is based show complete agreement between lake level cycles and independent magnetic polarity boundary isochrons. The main proxy of lake level and hence climate used to construct this lake level curve is a classification of water-depth related sedimentary structures and fabrics called depth ranks. We then use Fourier frequency analysis (both FFT and multitaper methods) and joint time-frequency approaches to resolve the periodic properties of the cyclicity and the secular drift in those properties. A consistent hierarchy in frequencies of the lake level cycles is present throughout the Late Triassic (and earliest Jurassic) portions of the cores, an interval of about $22 \mathrm{~m}$.y. Calibration of the sediment accumulation rate by a variety of methods shows that these thickness periodicities are consistent with an origin in changes in precipitation governed by celestial mechanics. The full range of precession-related periods of lake level change are present, including the two peaks of the $\sim 20,000$ year cycle of climatic precession, the two peaks of the $\sim 100,000$ year eccentricity cycle, the single peak of the 412,900 year eccentricity cycle, and the $\sim 2,000,000$ year eccentricity cycle. There is also good correspondence in the details of the joint-time frequency properties of lake level cycles and astronomical predictions as well. Even in an ice-free world, the tropical climate of Pangaea responded strongly to astronomical forcing, suggesting that precession-dominated climatic forcing probably always has been a prominent feature of tropical climate.
\end{abstract}

\section{Introduction}

Milankovitch theory predicts that variations in continental tropical climate will be dominated by insolation variations produced by the cycle of the precession of the equinoxes (Short et al., 1991; Crowley et al., 1992). However, largely due to logistical difficulties, there are no geologically longterm continental records from the present day tropics, for example, the East African rift lakes.
Thus, direct geological records for the long term behavior of tropical climate remain restricted to marine strata where the regional dynamics tend to be blurred by large scale integration of distant phenomena, such as polar ice sheets.

During the Late Triassic, there is no evidence of ice sheets even at the poles (Frakes and Francis, 1988), and the supercontinent of Pangaea lay astride the equator (Fig. 1). The initial phases of the breakup of Pangaea produced a series of 


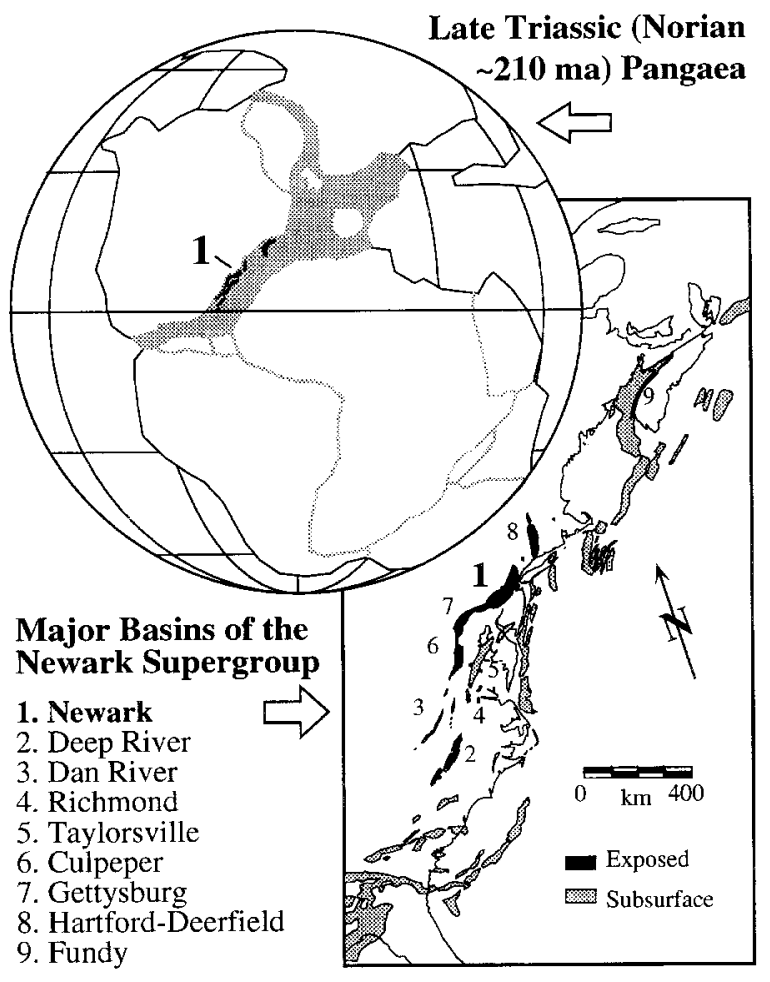

Fig. 1. Pangaea and the Newark Supergroup, showing the position of the Newark basin in Pangaea about midway through the NBCP core record. Figure modified from (Olsen et al., 1995).

continental rifts distributed along an almost northsouth transect across the equator. These basins subsided for over $30 \mathrm{~m} . \mathrm{y}$. during which many of them accumulated thousands of meters of largely lacustrine sediments. Today, the eroded remnants of these lacustrine rifts are exposed in eastern North America and allow relatively easy access to extremely long and continuous records of tropical climate change.

The Newark basin (Fig. 1) is one of the largest of these continental rifts and one with a very long lacustrine record, spanning nearly the entire Late
Triassic (Olsen, 1986; Cornet and Olsen, 1985; Cornet, 1977, 1993). During its depositional history, the basin drifted from 2.5 to $9.5^{\circ} \mathrm{N}$ latitude (Witte et al., 1991; Kent et al., 1995). Olsen (1986), following Van Houten (1964), showed that the relatively well exposed middle Lockatong Formation of the central part of the basin consists of cyclical lacustrine strata formed by lake level fluctuations controlled by astronomically forced cycles in precipitation. Although it seemed plausible that much of the rest of the basin section was characterized by similar cyclicity, poor exposure limited the available measured sections to less than $10 \%$ of the total present. It was therefore impossible to examine the long-term stability of the system or the judge the generality of the observed pattern. The exposure problem was remedied by coring at seven sites during 1990-1993 by the National Science Foundation-funded Newark Basin Coring Project (NBCP; Olsen and Kent, 1990), resulting in the recovery of over $6770 \mathrm{~m}$ of continuous core spanning virtually the entire Triassic age part of the Newark basin section. Most of this section is lacustrine and strikingly cyclical, comprising the longest record of continental tropical climate available anywhere (Olsen et al., 1996). In this paper, we describe the overall cyclostratigraphic, spectral, and joint time-frequency properties of the NBCP cores and relate them to Milankovitch forcing of continental climate in tropical Pangaea. This study forms the basis an understanding of the long term behavior of continental tropical climate change over a long stretch of geological time, and the foundation for an astronomically calibrated time scale for the Late Triassic (Kent et al., 1995).

\section{Newark basin stratigraphic section}

The Newark basin is an internally faulted half graben with the major SE- to S-dipping boundary

Fig. 2. Composite section and composite depth rank curve of the predominately lacustrine part of the NBCP core record. The ages, formations, and members are from Olsen et al. (1995); the $201 \pm 1$ age (Dunning and Hodych, 1990; Sutter, 1988) should apply to the Preakness Basalt. The filtered McLaughlin cycle was produced by filtering the depth rank curve with a zero-phase bandpass filter using minimum and maximum frequencies of 0.000122 and 0.001524 cycles $/ \mathrm{m}$, respectively. Key to the lithologies is in Fig. 3. NBCP core are: $P=$ Princeton; $N=$ Nursery; $T=$ Titusville; $R=$ Rutgers; $S=$ Somerset; $W=$ Weston; and $M=$ Martinsville. $A$ shows lower range of Army Corps of Engineers Cores. 


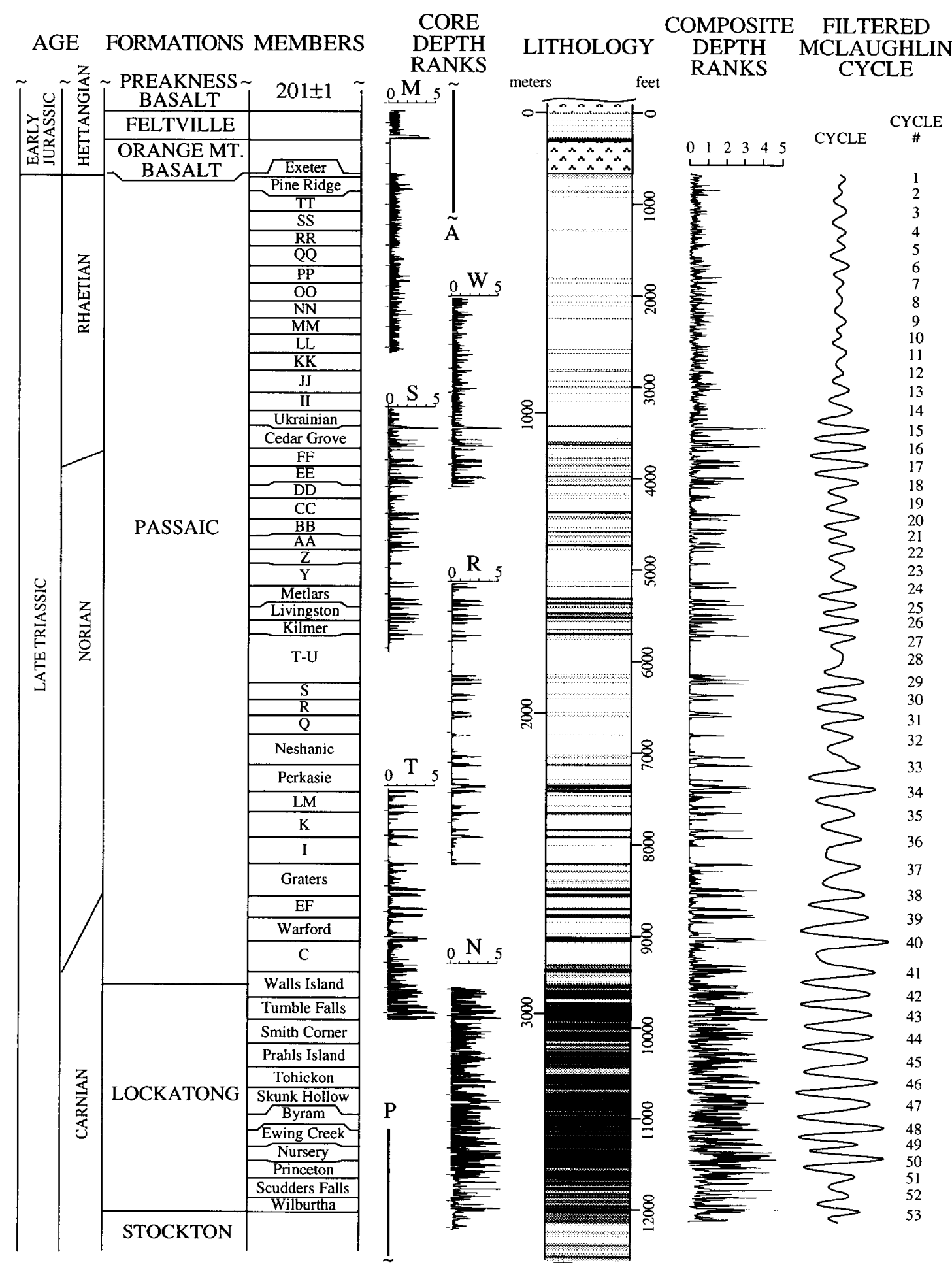


fault system on the northwest and with mostly northwest-dipping strata. Seven basin-wide formations are recognized (Olsen, 1980a,b) ranging in age from early Late Triassic (Carnian) to Early Jurassic (Hettangian) (Olsen, 1986; Cornet and Olsen, 1985; Cornet, 1977, 1993) (Fig. 2). The oldest outcropping unit is the mostly fluvial Stockton Formation of Carnian age. Throughout most of the basin this is followed by highly cyclical, predominantly lacustrine strata. The lowest of these lacustrine units is the mostly gray and black Lockatong Formation of Late Carnian (Tuvalian) age, and is overlain by the latest Carnian (Tuvalian) to earliest Jurassic (early Hettangian) age Passaic Formation, which is mostly red. Three Hettangian age tholeiitic lava flow formations (Orange Mountain, Preakness, and Hook Mountain basalts) and two interbedded, mostly red sedimentary units (Feltville and Towaco formations) conformably overlie the Passaic Formation; the youngest unit in the basin is the mostly red Boonton Formation also of Hettangian age. The lacustrine strata of the Lockatong and Passaic formations are further divided into 53 sequential members reflecting the cyclicity (McLaughlin, 1933, 1959; Olsen et al., 1996) (Fig. 2). The Newark basin section is described in detail from outcrops and core elsewhere (summarized in Olsen et al., 1995). In this paper we concentrate on the cyclical lacustrine Lockatong and Passaic formations because they preserve the longest unbroken record of orbital forcing.

An offset drilling method was used by the NBCP to obtain a stratigraphically continuous series of the Stockton through Feltville formations by coring at seven relatively shallow sites (Fig. 2). These sites were chosen to: (1) provide about $25 \%$ stratigraphic overlap between stratigraphically adjacent cores; (2) avoid any stratigraphic gaps or faults; (3) to remain in a fine-grained, centrally located portion of the basin; (4) to avoid large plutons or sills that might obscure aspects of lithology useful to cyclostratigraphy; and (5) to be as geographically close to each other as possible. For these reasons the core sites were arranged in two overlapping transects in central New Jersey. The drill cores averaged about $980 \mathrm{~m}$ of core per site with a nominal core diameter of $6.3 \mathrm{~cm}$. A total of about $6770 \mathrm{~m}$ of core was collected, with better than $99 \%$ recovery. The details of the drilling plan, surface geology, core locations, core stratigraphy, and logging results are summarized elsewhere (Olsen and Kent, 1990; Olsen et al., 1996, Kent et al., 1995; Goldberg et al., 1994).

The portions of the cores examined in detail here consist of the entire Late Triassic to earliest Jurassic age lacustrine section of the basin (Fig. 2). This comprises the section above the Stockton Formation in the Nursery core (Wilburtha-Walls Island members), all of Titusville (Tumble FallsPerkasie members), Rutgers (I-Y members), Somerset (T-U-II members), Weston (EE-OO members) cores, and the Martinsville core to the base of the Jurassic Orange Mountain Basalt (LL-Exeter members). The Princeton core (Wilburtha-Byram members) is not used here because its consists mostly of fluvial Stockton Formation, and the lacustrine portions completely overlap with the Nursery core section. The postPassaic portions of the NBCP cores and other cores drilled by the Army Corps of Engineers in the Jurassic age part of the section (ACE cores) are used here only to constrain the age model for the underlying lacustrine section.

\section{Typological cycle types}

Newark basin lacustrine strata have been described as cyclical for over 60 years (McLaughlin, 1933). Van Houten (1962, 1964, 1969) described the cyclicity of the Lockatong Formation in detail and recognized a hierarchy of cycles based on changes in sedimentary rock type and structures that he ascribed to changes in lake levels controlled by astronomical forcing of climate. Based largely on the NBCP cores, Olsen et al. (1996) use a modified version of Van Houten's classification of cycle types, which we adopt here.

In typological terms, the most obvious cycle at the outcrop scale is the Van Houten cycle, named after its discoverer (Van Houten, 1962, 1964, 1969) (Fig. 3). Each Van Houten cycle consists of three divisions (Olsen, 1986). Division 1 (lake transgression) is a relatively thin unit, generally massive at 
A

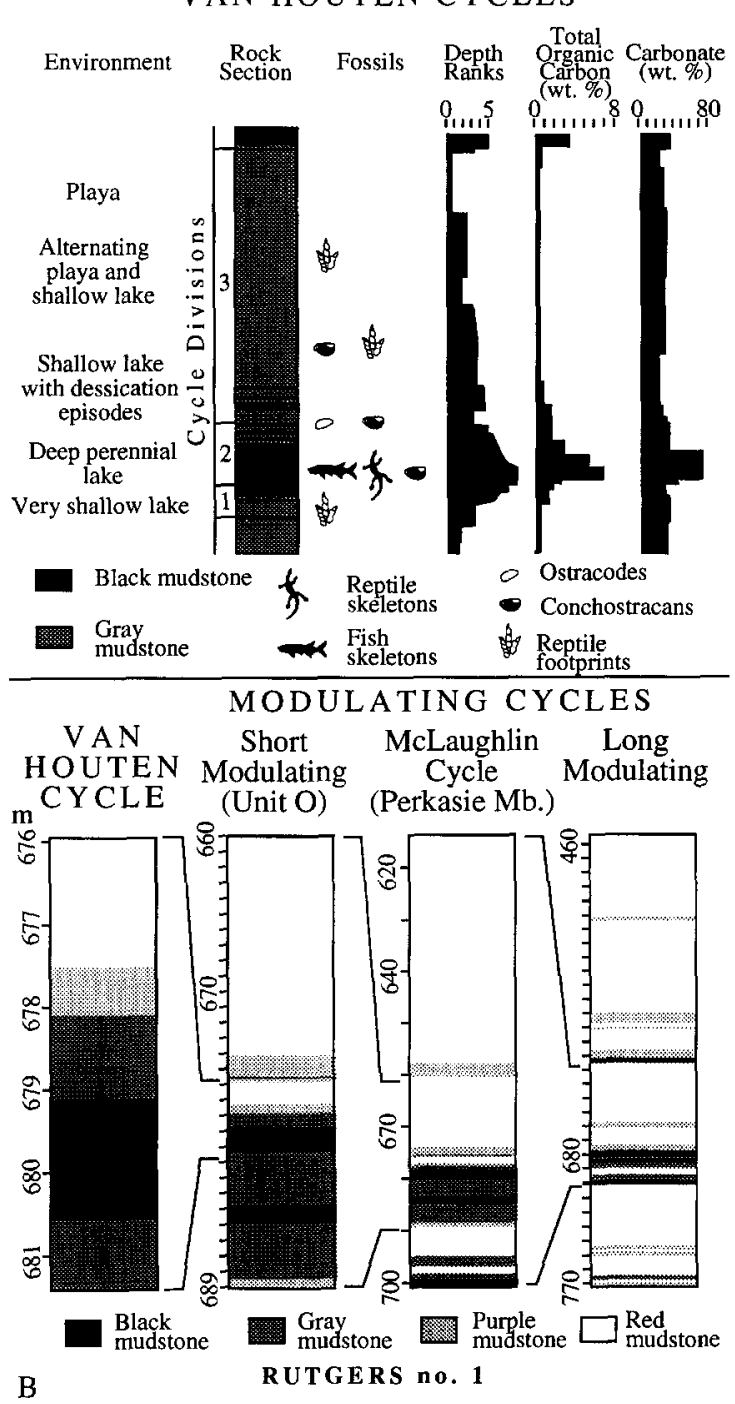

Fig. 3. Typological classification of lake level cycles in the Newark basin. A. The Van Houten cycle. B. Modulating cycles (example from the Rutgers no. 1 core). Figure modified from Olsen et al. (1995).

its base, becoming better bedded upwards as the density of desiccation cracks and/or tubes (roots or burrows) decreases. Reptile footprints are sometimes common. Division 2 (lake high stand) has the best developed bedding in the cycle and commonly consists of gray or black, often calcareous fissile mudstone often with elevated total organic contents $(1-8 \%)$. In some cases the most finely laminated of these organic rich units contains abundant complete fossil fish and reptiles. Division 3 (lake regression) becomes more massive upwards by an increase in the frequency of desiccation cracks and/or tubes. Reptile footprints are sometimes present. Divisions 1 and 3 may be gray, purple or red with lighter colors predominating, while division 2 can be red, purple gray or black with darker colors being common. Evaporite pseudomorphs are often present in the upper parts of division 2 and 3 (E1 Tabakh, 1994). A Van Houten cycle thus records a single cycle of lake deepening and then shallowing, presumably in response to a similar dry-wet-very dry cycle in climate. In the NBCP cores, Van Houten cycles tend to average about $4 \mathrm{~m}$ in thickness. Variations in the character of Van Houten cycles in these cores have been described in detail by Smoot and Olsen (1994).

Van Houten cycles are modified in their expression by at least three orders of modulating cycles which we term the short, intermediate (McLaughlin), and long modulating cycles (Fig. 3). This modulation is expressed in the degree of development of lamination and black and drab colors in Van Houten cycles. In the "peaks" of each of these modulating cycles, Van Houten cycles tend to be dominated by drab and dark colors (relatively deeper lakes and wetter climates); division 2 tends to be thick, black and finely laminated indicating deep, perennial lakes. In the "troughs" of the modulating cycles, the Van Houten cycles tend to be mostly red (shallow lakes and playas and drier climates), and division 2 is usually red, purple, or gray fissile mudstone, suggesting shallow lakes or playas. On average, the short modulating cycles contain five Van Houten cycles (range of four to six), the McLaughlin cycles contain four short modulating cycles, and the long cycles contain four to five McLaughlin cycles. The expression of McLaughlin cycles is the strongest and that of the long modulating cycles is the weakest.

All of the modulating cycles are visible at map scale. The basis for subdivision of the Lockatong and Passaic formations into the 53 formally and informally named members is, in essence, the McLaughlin cycle, named for D.B. McLaughlin who first recognized them as an integral part of Newark basin stratigraphy (McLaughlin, 1933, 
1959; Olsen et al., 1996). McLaughlin himself (1933, 1946, 1959) mapped the distribution and named the gray portions of both the short modulating cycles and the McLaughlin cycles in the upper Lockatong and lower Passaic formations in the central Newark basin. All of the formally named members of the Passaic Formation occur in the "peaks" of the long modulating cycles (e.g. Graters, Perkasie, Metlars members, etc.; Fig. 2), and therefore, McLaughlin also implicitly recognized this modulating cycle as well.

\section{Depth ranks as proxies of climate}

The typologically defined cycles are conceptually useful for understanding and describing the cyclicity, but we seek a measure of lake depth more suitable for numerical analysis of the cyclicity and quantitative comparison to astronomically based climate predictions. Such a proxy should be a numerical scalar variable that can be measured as a function of stratigraphic depth, that has a fairly direct relationship to climate, and that does not have the cyclicity imbedded in it. In fact, the typological classification method itself suppresses the real variability caused by the interactions of the many cycles that would be expected to produce the climatic forcing in the first place.

The most obvious proxy of climate consistently preserved in the NBCP cores is the variation in lithology and sedimentary structures (i.e. facies) reflecting change in the level of lakes. We use a semi-quantitative classification of these sediment structures and fabrics called "depth ranks" (Olsen, 1986) for most of our analysis. Depth ranks are a sequence of facies related to the inferred relative depth of the lake during deposition (Fig. 4; Table 1). The overall direction of environmental change represented by these facies is fairly obvious and they provide the most direct measure of relative lake level and hence climate presently available for these rocks. At one extreme is rank 0, which consists of massive, often red mudstones with intensely mudcracked or rooted sedimentary fabrics. These fabrics were produced by playas or vegetated dry lakes (Smoot, 1991; Smoot and Olsen, 1994). At the other extreme is rank 5 comprised of microlaminated, usually black and organic-rich calcareous mudstones frequently con- $\mathbf{0}$

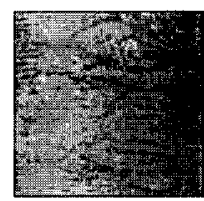

Intense breccia fabric

0

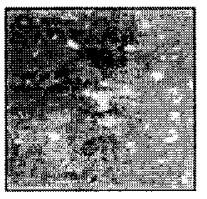

Massive rooted and mudcracked mudstone
1

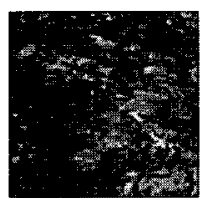

Breccia fabric

1

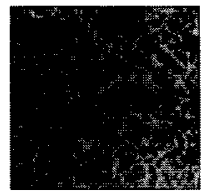

Cement-filled rooted

mudstone
2

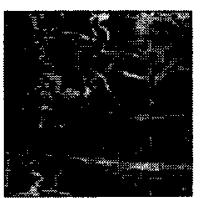

Mudcracked mudstone
3

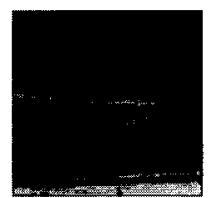

Thin-bedded non-muderacked mudstone
4

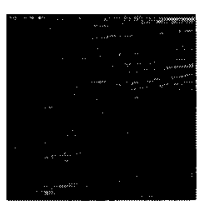

Finely laminated mudstone
1

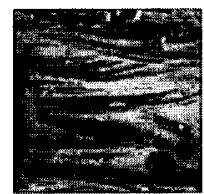

Fine rippled sandstone
5

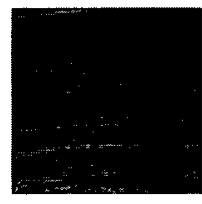

PRIMARY RANKS
SECONDARY RANKS

Fig. 4. Photographs of representative sedimentary structures and fabrics comprising of the depth ranking scheme described in the text and Table 1. The examples shown have the following locations in the cores. Primary ranks (all from Nursery no. 1): $0=1522.2$ $\mathrm{ft} ; l=312 \mathrm{ft} ; 2=1537 \mathrm{ft} ; 3=2109 \mathrm{ft} ; 4=1800 \mathrm{ft} ; 5=2376 \mathrm{ft}$. Secondary ranks (from Martinsville no. 1 ): $0=1193 \mathrm{ft} ; l=2858 \mathrm{ft} ; l=$ Tertiary ranks (from Martinsville no. 1): $1=1728 \mathrm{ft} ; 2=2873 \mathrm{ft}$. Each photograph covers about $16 \mathrm{~cm}^{2}$. 


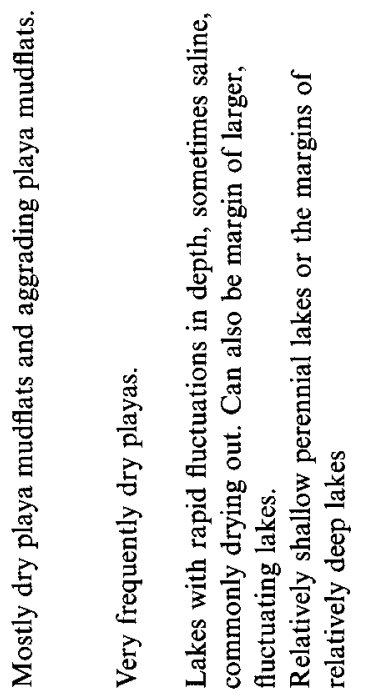

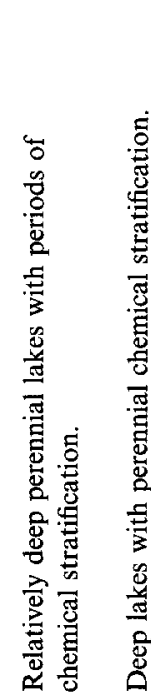

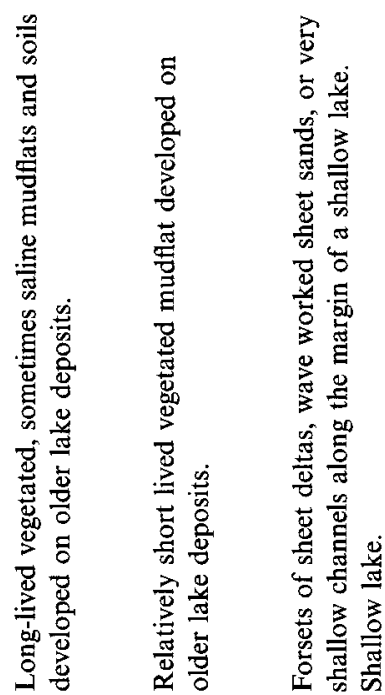

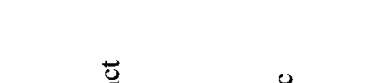

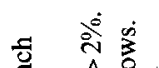

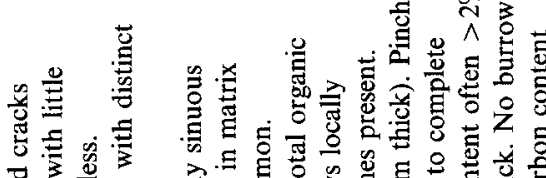

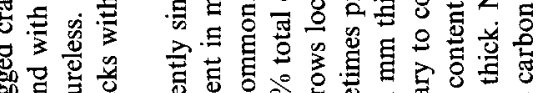

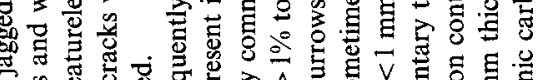

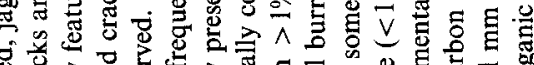

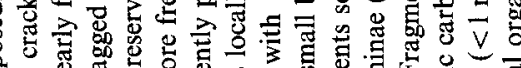

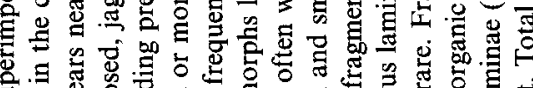

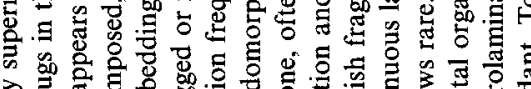

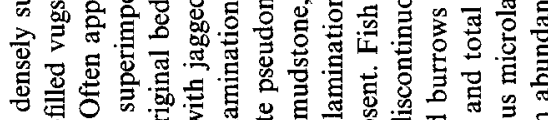

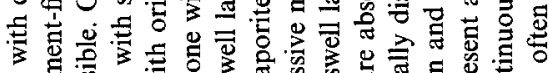

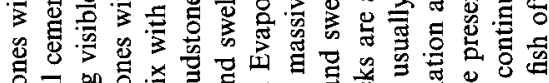

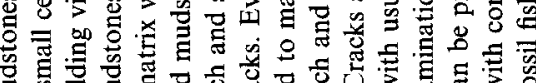

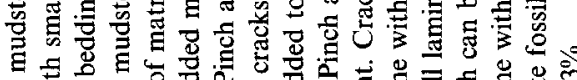

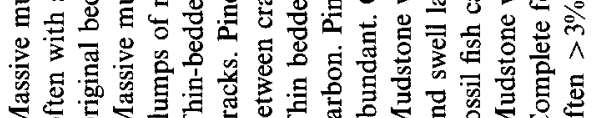

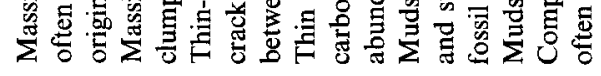
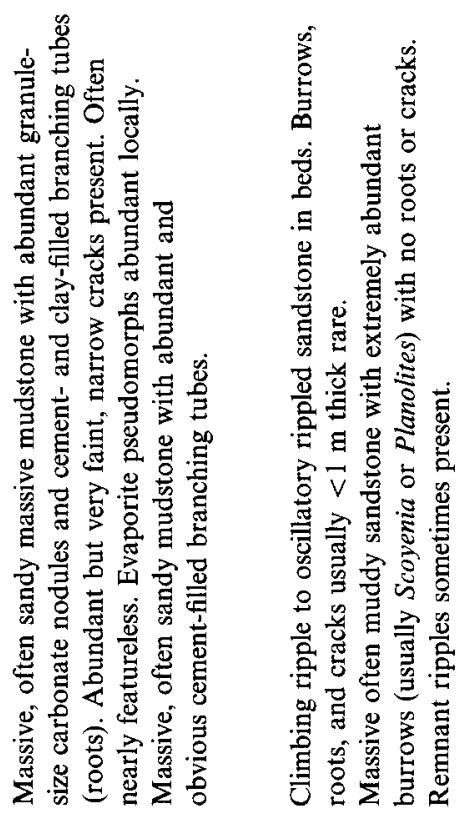

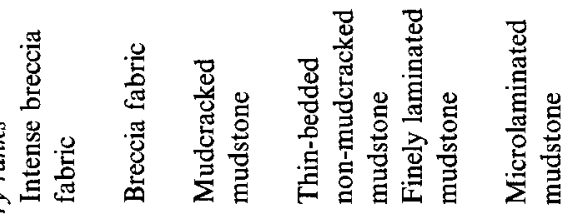
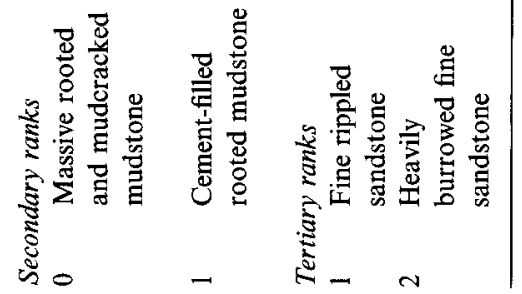
taining completely preserved fossil fish and aquatic reptiles. This facies was produced by deep $(>80$ m) perennially stratified lakes (Olsen, 1990; Smoot, 1991). Beds of low depth rank (1-2) often preserve reptile footprints, and beds with higher ranks (3-4) often contain fish fragments. Low depth rank units are often red and contain little or no organic carbon and often contain evaporite pseudomorphs. High depth rank units are usually gray or black with correspondingly elevated total organic carbon contents $(>2 \%)$.

A single sequence of mudstone facies (i.e. the primary depth ranks, Fig. 4) accounts for most of the variability in the cores. However, the upper Passaic Formation and the basal Lockatong Formation have sandstone and sandy mudstone facies that cannot be interpolated into the sequence of primary depth ranks. Thus, we use two subsidiary and parallel depth rank scales (secondary and tertiary), in addition to the primary sequence, for the coarser-grained shallow-water facies (Fig. 4). The equivalence of these three depth rank series was determined by lateral change of portions of individual cycles into different facies (McLaughlin, 1946; Olsen, 1988), the intimate interbedded relationship of equivalent facies in some portions of the cores, and the equivalence of position within typologically defined cycles.

The variations in depth rank produce the obvious cyclicity already typologically described from outcrops and cores (Olsen, 1986; Olsen et al., 1996; Van Houten, 1962, 1964, 1969; Smoot and Olsen, 1988, 1994; Smoot, 1991). In terms of the divisions of Van Houten cycles, division 1 is characterized by low depth ranks (0-2); division 2 always has higher depth ranks (1-5) than division 1; and division 3 returns to low depth ranks (0-2).

Intervals (or bands) of common depth rank were recorded using the scale in decimal feet marked on the cores by the drillers. Numerical analyses were conducted in the units of original measurement to avoid unnecessary rounding error; however, we have converted these measurements to metric dimensions for this paper. The range of thicknesses of intervals characterized by a single depth rank is from less than $\sim 30 \mathrm{~cm}(1 \mathrm{ft})$ to more than $\sim 10 \mathrm{~m}(30 \mathrm{ft})$. The data series was interpolated to a constant increment $(\sim 15 \mathrm{~cm} ; 0.5$ $\mathrm{ft}$ ) to capture the smallest measured depth rank interval. The interpolation results in some fractional depth ranks as seen in the figures. Depth rank curves for individual cores are shown in Fig. 2. In general, average depth ranks are highest in the oldest part of the section (Lockatong Fm., Nursery core) and lowest in the youngest part of the section (upper Passaic Fm., Martinsville core).

Although the determination of depth ranks has a subjective element, their climatic significance is fairly straight forward. Moreover, more "objective", although less direct, descriptors such as geophysical logs of the cores and core holes or chemical properties do tend to correlate with depth rank (Fig. 5). There is an especially good correlation with the reflection coefficient which is derived from the sonic velocity and density logs (Reynolds, 1993; Baker, 1994). The changes in facies represented by the vertical changes in depth ranks were produced by lake level changes that also strongly influenced cementation of the mudstones, with higher levels of cementation (associated with deeper lakes) tending to have higher densities and sonic velocities (Reynolds, 1993). Organic carbon also positively correlates with depth rank and because uranium tends to concentrate in organicrich units there is also correlation between depth ranks and the gamma logs. All of these properties have potential for understanding Newark basin cyclically (Reynolds, 1993). Many other potential proxies of climate such as $\delta^{18} \mathrm{O}$ or pollen and spores either have not been adequately tested (El Tabakh, 1994) or are too sporadically preserved (Fowell, 1993) in these diagenetically altered rocks to be used to produce a time series.

Depth ranks have excellent lateral continuity showing that their vertical variations reflect basinwide change in lake depths (McLaughlin, 1946; Olsen, 1988). This is best seen in the overlap zones between stratigraphically adjacent cores where all of these correlations have been tested by downhole logging and magnetostratigraphy (Olsen et al., 1996; Kent et al., 1995) (Fig. 2). There is a one to one match between variations in depth ranks in the correlative sections, even over distances of more than $40 \mathrm{~km}$ (the distance between the Rutgers and Titusville cores). In addition, outcrop sections show very similar depth rank patterns to the 


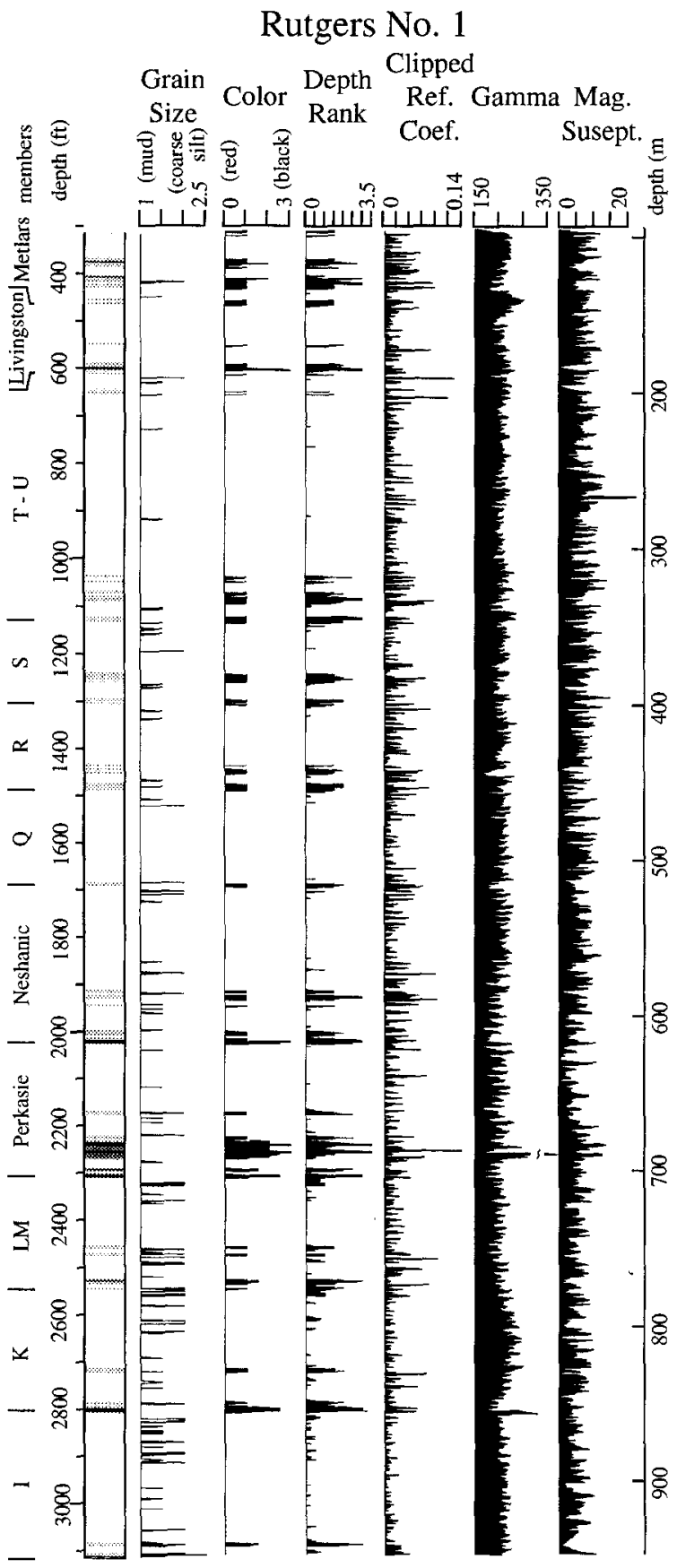

Fig. 5. Comparison of different lithological and geophysical properties of the Rutgers no. 1 core and associated down-hole logs. Note especially the close correspondence between depth rank and the clipped reflection coefficient (negative values deleted). correlative sections. A good example is the long classic outcrop sequence along the Delaware River near Byram, New Jersey (Fig. 6). This is one of the main sections on which Van Houten (1969) based his interpretation and which subsequently was measured using a depth rank method (Olsen, 1986). The Byram section correlates very well with the equivalent section in the Nursery core, despite some difficulties with locally poor exposure. The core and outcrop examples cited here are in three different fault blocks with markedly different accumulation rates (as judged from the cycle thicknesses); the strong similarity in depth rank patterns in correlative sections shows that the lake level changes were synchronous over very large areasprobably basin wide. Hence depth ranks are a good proxy of the aspects of the climate system that controlled precipitation and evaporation.

\section{Composite record}

Lithological and magnetostratigraphic correlation between the overlap zones of stratigraphically adjacent cores reveal significant changes in accumulation rate with geographic position in the basin ranging from about 5 to $22 \%$ in stratigraphically adjacent core holes (Olsen et al., 1996). Lateral variations in accumulation rate are expected in a large half graben (Schlische, 1992), but they need to be factored out in the construction of a composite depth rank series to isolate the variations of frequency properties as a function of stratigraphic position or time. Several corrections were also needed to transform the drillers' depth scale to actual stratigraphic depth, including registering the cores to the core holes and correction for hole deviation and stratal dip. The procedure for the correlations and construction of the composite are given in detail by Olsen et al. (1996) and summarized below.

First, where more than one core was taken at a site, the cores were patched together using shared lithologically distinctive beds. Second, we adjusted depth marked on the core to stratigraphic thicknesses by correcting core depth to depth-in-hole using the natural gamma logs from the core and core hole, and then transforming depth-in-hole to 


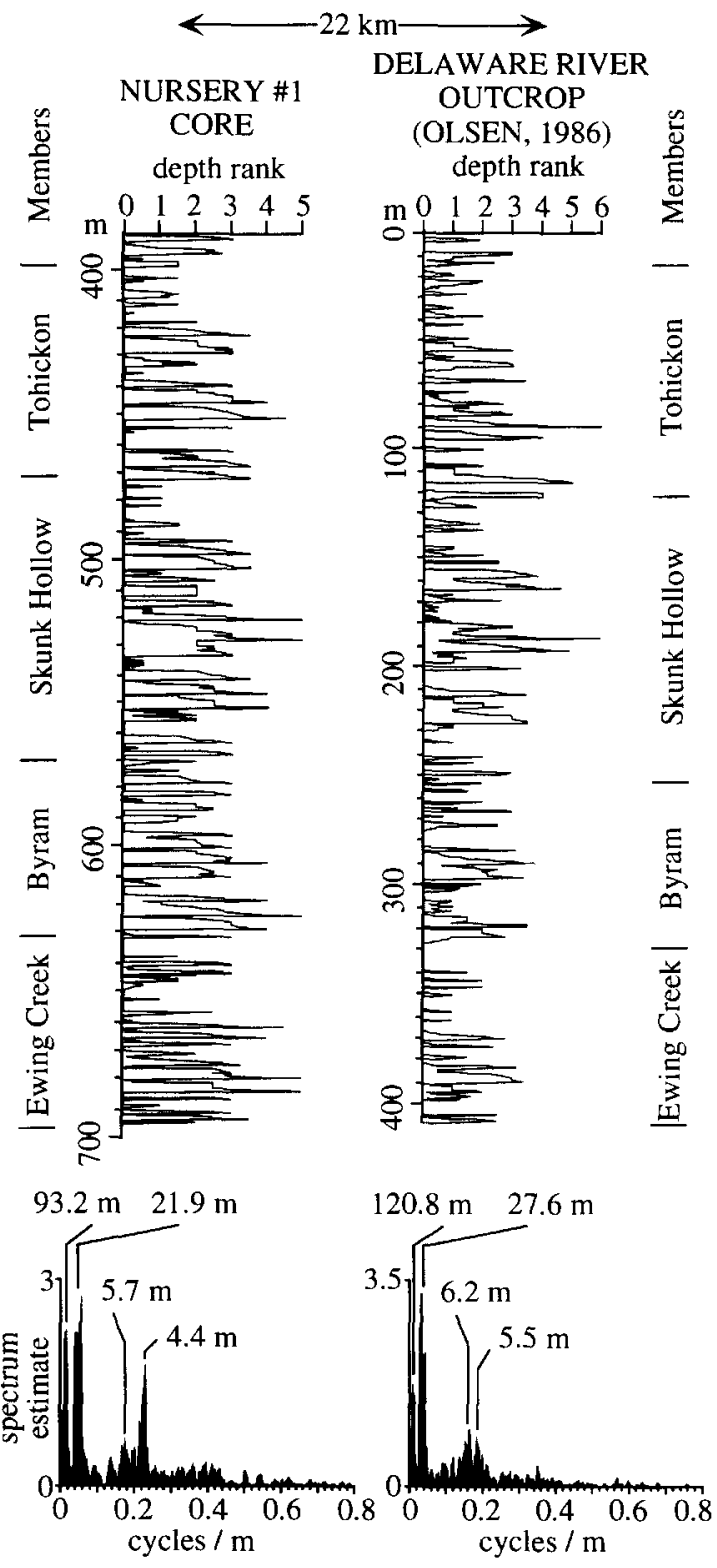

Fig. 6. Comparison between depth rank curves of a portion of the Nursery core and outcrops of the middle Lockatong formation along the Delaware River in Byram, New Jersey. The outcrop section was measured in 1983 using a slight variant of the depth rank scale used here ( 7 instead of 6 ranks) and published in 1986 (Olsen, 1986) and is in a different fault block than the core. Note the difference in scale. Spectra below the sections are multitaper spectrum estimates with values of periods of cycles in thickness expressed as time as follows: Nursery \# 1 core, $93.2 \mathrm{~m}=412.9$ k.y., $21.9 \mathrm{~m}=97.0 \mathrm{k} . \mathrm{y} ., 5.7$ $\mathrm{m}=25.3$ k.y., $4.4 \mathrm{~m}=19.5 \mathrm{k} . \mathrm{y}$; outerop, $120.8 \mathrm{~m}=412.9$ k.y., $27.6 \mathrm{~m}=94.3 \mathrm{k} . \mathrm{y} ., 6.2 \mathrm{~m}=21.2 \mathrm{k} . \mathrm{y} ., 5.5 \mathrm{~m}=18.8 \mathrm{k} . \mathrm{y}$. Spectral estimates were computed with the same parameters as in Fig. 8 . stratigraphic thickness using the hole deviation and dipmeter surveys. These modifications were small, averaging $0.5 \%$. Third, we selected correlation tie points for the overlap zones of stratigraphically adjacent core holes, usually distinctive highdepth rank shales within division 2 of Van Houten cycles. The slopes of the regression lines for the tie points are the scaling factors (i.e. proportionality constants) between overlap zones. Fourth, we scaled the other cores to the Rutgers cores as a standard using the scaling factors, beginning at the Rutgers overlap zones, and proceeding up and down section. Fifth, stratigraphically adjacent core records were patched together at distinctive tie points, with the down-dip (or higher accumulation rate) portions of cores given preference in the overlap zones. The composite stratigraphic section (Fig. 2) is thus scaled as it might appear if the whole section had been cored at the Rutgers geographic core site. It should be noted, however, that the scaling process used in the construction of the composite section accounts only for the sedimentation variations between the coring sites, not potential changes in depth rank due to differing positions of the cores in the basin. A comparison of the depth ranks in the overlap portions of the cores, however, shows that this effect is small (Fig. 2).

\section{Spectral analysis}

The frequency and spectral properties of the cores are first examined by stratigraphic length (or space) in the core as a proxy of time. We then develop an age model, based on correlation to published time scales and on the spectral properties themselves, and examine the resulting time series.

A simple power spectrum (using a fast Fourier transform) of the entire composite depth rank series shows a number of well defined peaks (Fig. 7, top). However, the large dynamic range of the data series, the large-scale changes in variability with stratigraphic position, and smearing out of spectral power in the higher frequencies suggest that an evolutive method would better isolate the true frequency behavior of the data.

The time-frequency, or more appropriately in 


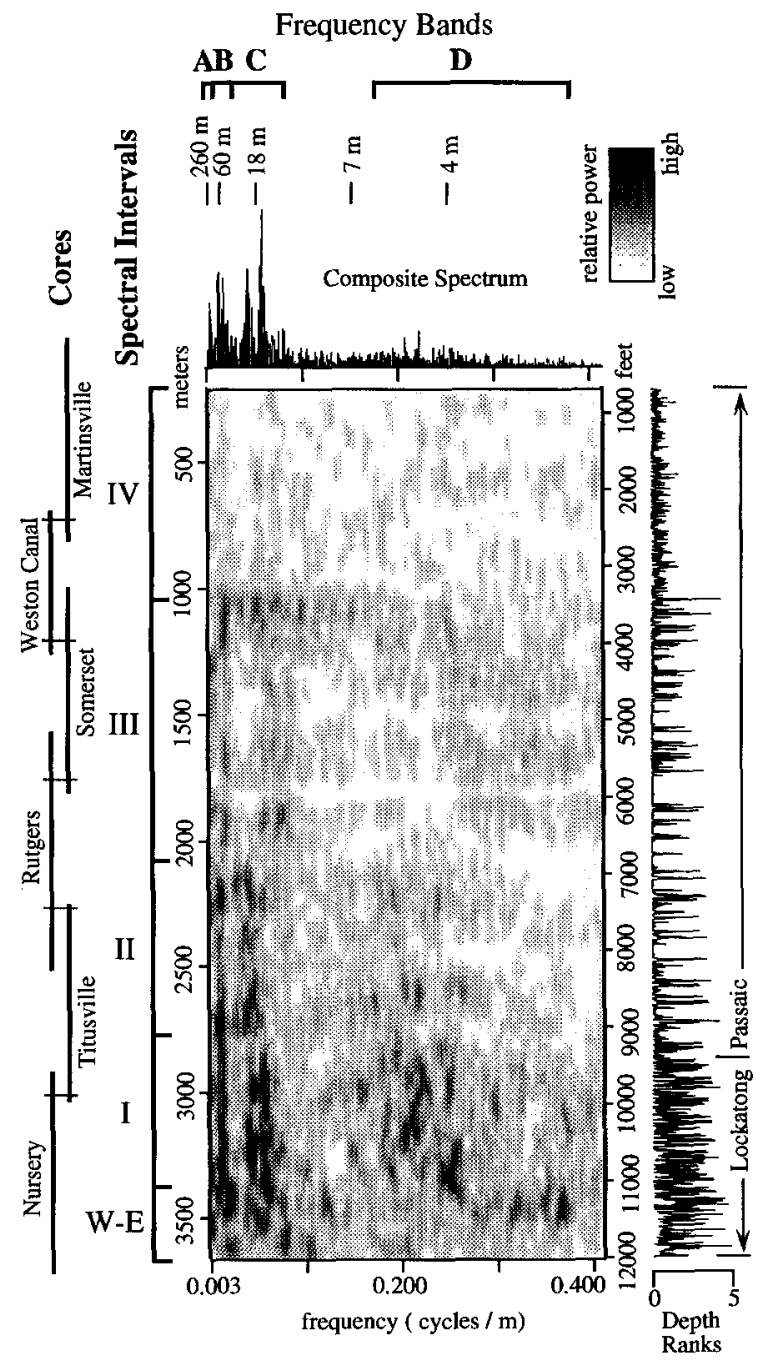

Fig. 7. Space-frequency spectrogram for the post-Stockton, pre-Orange Mountain Basalt portion of the NBCP cores. Frequency bands are: $A=$ the long modulating cycle; $B=$ the McLaughlin cycle; $C=$ the short modulating cycle; and $D=$ the Van Houten cycle. Spectrogram uses a short-time-Fourier transform computed with a $61 \mathrm{ft}$ ( 200 point) moving Hanning window and was produced using Lab View ${ }^{\mathrm{TM}}$ (National Instruments). Spectral intervals $\mathrm{W}-\mathrm{E}$ and I-IV are described in text.

this case, space-frequency spectrogram (Cohen, 1992; Percival and Walden, 1993), is an evolutive method designed to show changes in frequency and spectral power as a function of another variable such as time or space. Such a spectrogram of the Lockatong and Passaic formations is shown in Fig. 7 (bottom). Although the Van Houten cycles are the most obvious quasiperiodic cycle at the outcrop scale, the lower frequency modulating cycles are the most obvious in the space-frequency spectrogram of the entire cyclical sequence. The long-modulating cycle $(250-430 \mathrm{~m}$ period) is reflected in the rhythmic pulsations in the spectral power of the other frequencies, the window length in the spectrogram being too short to resolve it as a distinct band of spectral power. The most obvious vertical dark stripe on the left of the spectrogram shows that there is a cycle with high power around 0.017 cycles $/ \mathrm{m}(60 \mathrm{~m} /$ cycle space period $)$, corresponding to the McLaughlin cycle. Power in this frequency band is consistently present throughout the composite sequence, although there are distinct lateral shifts in its position, corresponding to shifts in accumulation rates. The spectrogram also shows that the relative power of the McLaughlin and other cycles decreases from the lower to the upper parts of the sequence. Likewise, there is a pair of strong bands in spectral power consistently present around 0.056 cycles $/ \mathrm{m}$ (18 $\mathrm{m} /$ cycle) corresponding to the short modulating cycle; they follow the same pattern of shifting frequencies as the McLaughlin cycle. Finally, there is significant power in the frequency band from about $0.143-0.250$ cycles $/ \mathrm{m}(7-4 \mathrm{~m} /$ cycle $)$, most obvious in the lower part of the cyclical sequence. These frequencies correspond to the Van Houten cycles.

The space-frequency spectrogram of the Lockatong and Passaic formations can be divided into five easily recognizable stratigraphic intervals, recognized by lateral shifts of frequency bands indicating changes in accumulation rate, and variation in amplitude of the bands indicating changes in the variance in depths of the lakes (Fig. 7). None of the transitions between these spectral intervals occur at a tie-point between cores. The transitions between spectral intervals therefore represent changes with stratigraphic depth and not geography.

The basal interval (W-E, Fig. 7) includes the 5 McLaughlin cycles from the Wilburtha through Ewing Creek members of the Lockatong Formation. This interval is transitional from the 
underlying mostly fluvial Stockton Formation and is characterized by relatively inconsistent spectral properties and lithological patterns. The lower members of interval W-E (Wilburtha, Scudders Falls, and Princeton) are very sandy. Based on seismic lines (Reynolds, 1993) and correlation between the Nursery and Princeton cores and outcrop (Olsen et al., 1995), this interval has a significant and quite variable deltaic component. The overlying Nursery and Ewing Creek members in interval $\mathrm{W}-\mathrm{E}$ consistently have the thinnest cycles ( $\sim 3 \mathrm{~m}$ per Van Houten cycle) of the entire core section even though they are dominated by Van Houten cycles with the best developed black shales and correspondingly highest depth ranks in the cored interval. These Van Houten cycles mostly correspond to type I in the classification of Smoot and Olsen (1994), reflecting the expansion and contraction of deep lakes often with perennial chemical stratification (Olsen, 1990). Cycles of type II are also present in this interval, and they represent shallower lakes with some evaporite development.

The remaining four spectral intervals in the Lockatong and Passaic formations (spectral intervals I-IV) have internally consistent but mutually distinct spectral properties. We examine each of these spectral intervals separately by using the multitaper spectrum estimate method of Thomson (1990a,b) (Fig. 8) as well as detailed joint space-frequency spectrograms (Figs. 9-12).

Interval $I$ is comprised of the Byram Member of the Lockatong Formation through member $\mathrm{C}$ of the Passaic Formation, and thus consists of 8 McLaughlin cycles. This interval has the most consistent spectral properties of the entire cored
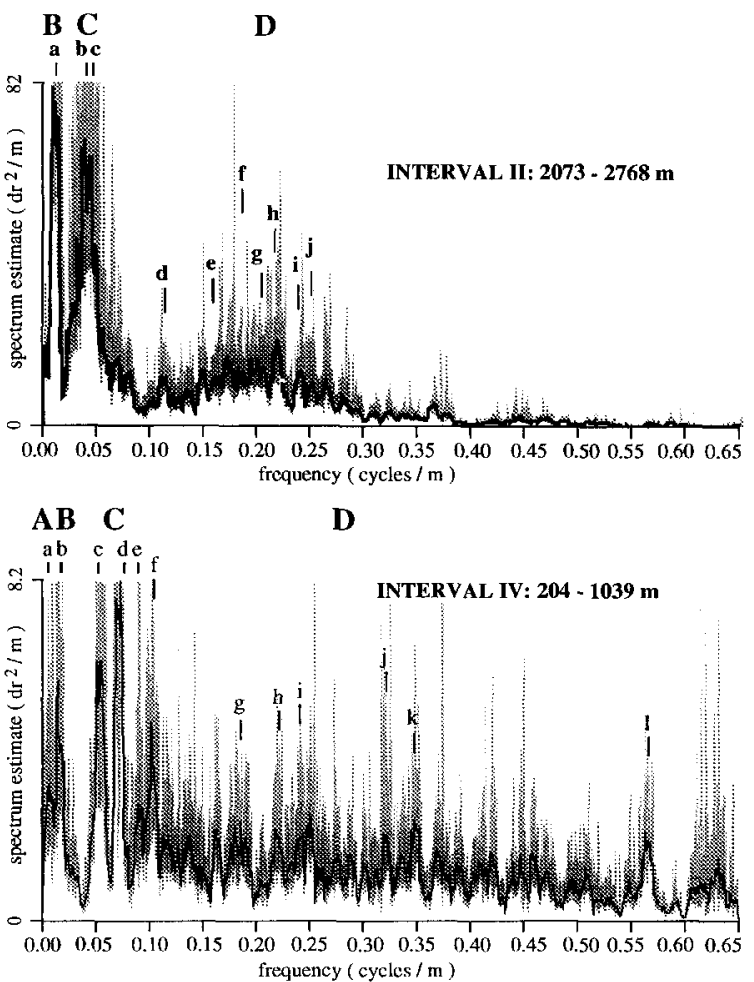

Fig. 8. Multiple-window spectrum estimate (Thomson, 1990a,b) of spectral intervals I-IV (Fig. 7). Shaded zone shows $90 \%$ confidence intervals (upper limit locally truncated). Specific spectral peaks are labeled (Table 2) that both pass $t$-test at $p=0.05$ level and lie on intervals of high spectral power. Frequency bands are as in Fig. 7. Spectrum computed using half bandwidth (NW) of $3.5,6$ orders of eigenspectra, $\mathrm{Dt}=1 \mathrm{ft}$, and with the time scale set by assuming that spectral peaks $a, a, b$, and $b$ in spectral intervals I, II, II and IV are the $412.9 \mathrm{ky}$ cycle, respectively (Table 2). 
Spectral Interval I

D

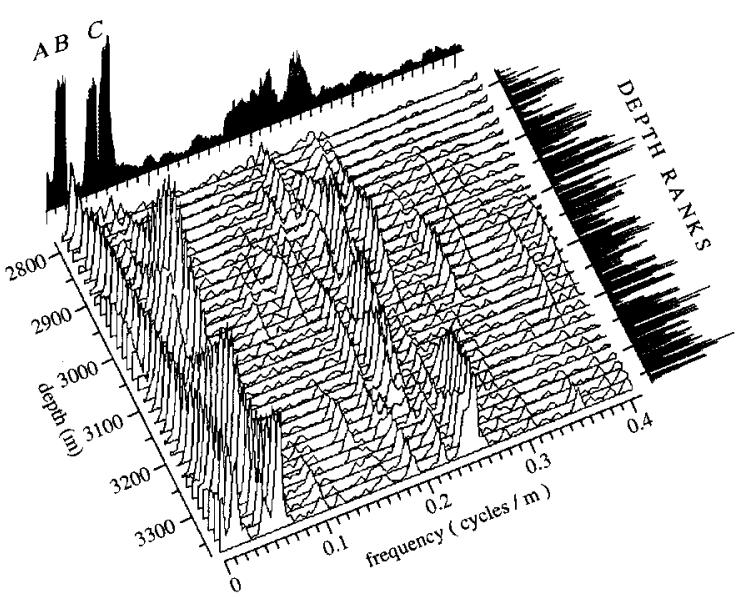

Fig. 9. Joint time-frequency spectrum of interval I. Note the continuity of most spectral peaks and the consistent presence of two parallel sets of peaks around 0.015 cycles/ $\mathrm{ft}$ (period of $67 \mathrm{ft}-112 \mathrm{ky}$ ). Frequency bands are: $A=$ long modulating cycle; $B=$ McLaughlin cycle; $C=$ short modulating cycle; $D=$ Van Houten cycle. Same time-frequency parameters as Fig. 7.

section (Fig. 8). It is therefore not surprising that the outcrop correlative of a substantial part of this section was the basis for the initial interpretation of the Milankovitch origin of the cyclicity (Van Houten, 1969; Olsen, 1986) (Fig. 6). Interval I is characterized by having strong and significant peaks in power at 0.217 and 0.258 cycles $/ \mathrm{m}(4.6$ and $3.9 \mathrm{~m}$ periods) with another significant peak at $0.182 \mathrm{cycles} / \mathrm{m}(5.5 \mathrm{~m}$ period), all in the frequency band of the Van Houten cycles. The short modulating cycle frequency band is split into two significant peaks at 0.044 and 0.057 cycles/m (22.8 and $17.4 \mathrm{~m}$ periods). The frequency band of the McLaughlin cycle is at 0.014 cycles $/ \mathrm{m}(73.9 \mathrm{~m}$ period). A detailed space-frequency spectrogram of interval I shows little change in frequency with space, although there is considerable amplitude variation (Fig. 9). Especially important is the consistent presence of two major peaks in the short modulating cycle and a tendency for there to be two major peaks in the Van Houten cycles, because these are unique predictions of celestial mechanics (Berger, 1977) (see below).

The passage from the transitional beds of the lowermost Lockatong into the beds of spectral interval I reflects the appearance of abundant massive mudstones with a well developed breccia fabric. The Van Houten cycles of interval I reflect deep perennial lakes, which had rare periods of stable chemical stratification, alternating with playas in which limited evaporites often formed (El Tabakh, 1994). The division between the intervals corresponds to the upward replacement of Van Houten cycle types I and II by type III of Smoot and Olsen (1994), showing a marked increase in the frequency of playas and a corresponding decrease in the frequency and duration of long-lived deep perennial lakes.

Interval II $(2073-2768 \mathrm{~m})$ is composed of the Warford through Neshanic members of the Passaic Formation ( 8 McLaughlin cycles). The overall spectrum estimate of this interval is not as consistent as for interval I, although the same components are clearly present but shifted to lower spatial frequencies (Fig. 8). In addition to a change in amplitude, the patterns of spectral power in intervals I and II differ mostly by a constant that we interpret as the ratios of the accumulation rates of the two intervals (in this case 1.14, see below). While Van Houten cycles are obvious on visual inspection of the cores and outcrops, their frequencies in the spectrum are less distinct. The same holds to a lesser extent for the short modulating cycle, although there are still two significant peaks ( 0.042 and 0.47 cycles/ft -23.7 and $21.2 \mathrm{~m} /$ cycle) . The McLaughlin cycle is fairly consistent at 0.012 cycles $/ \mathrm{m}(85.1 \mathrm{~m} /$ cycle $)$. Closer inspection of the detailed space-frequency spectrogram of interval II (Fig. 10) reveals that the short modulating cycle is still consistently split into two strong frequencies and that the smearing in the spectrum is due to small frequency shifts with stratigraphic position. The same is true for the Van Houten cycles which tend to consist of two sets of prominent peaks that drift in frequency through the interval.

The transition from interval I to II is marked by a change from predominately gray and black units to predominately red beds. It is offset upward, however, by one member from the boundary between the Lockatong and Passaic formations (Fig. 7). In terms of the classification of Smoot and Olsen (1994), Van Houten cycle type III 


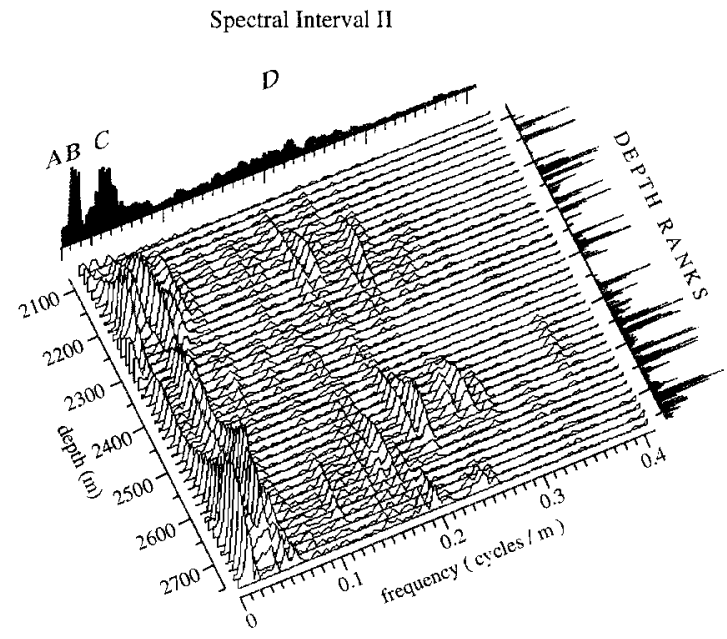

Fig. 10. Joint time-frequency spectrum of interval II. Same abbreviations and parameters as Fig. 9.

becomes more common than type II, indicating a further increase in the frequency of playas at the expense of perennial lakes.

Interval III (1064-2073 m) is the thickest in the composite core record, consisting of 17 McLaughlin cycles (member $Q$ through the Ukrainian Member of the Passaic Fm.). It is characterized by a shift back to slightly higher frequencies in all bands and shows an additional smearing of the spectral power (Fig. 8). This smearing is especially apparent in the short modulating and Van Houten cycles; however, two significant peaks in the range of the short modulating cycle $(0.057$ and 0.076 cycles $/ \mathrm{m} ; 17.5$ and 13.2 $\mathrm{m} /$ cycle) are still detectable in the detailed joint space-frequency (Fig. 11).

The transition from interval II to III is marked by an increase in sand as well as bioturbated fabrics, and, consequently, the secondary and tertiary depth rank sequences become more important. It also corresponds to the transition from mostly type II and III Van Houten cycles to dominantly type IV (Smoot and Olsen, 1994), reflecting a return to moister conditions on a broadened basin floor.

Interval IV shows a decrease in the expression of all cycles, especially Van Houten cycles. This interval comprises member II through the Exeter Member of the Passaic Formation (14 McLaughlin
Spectral Interval III

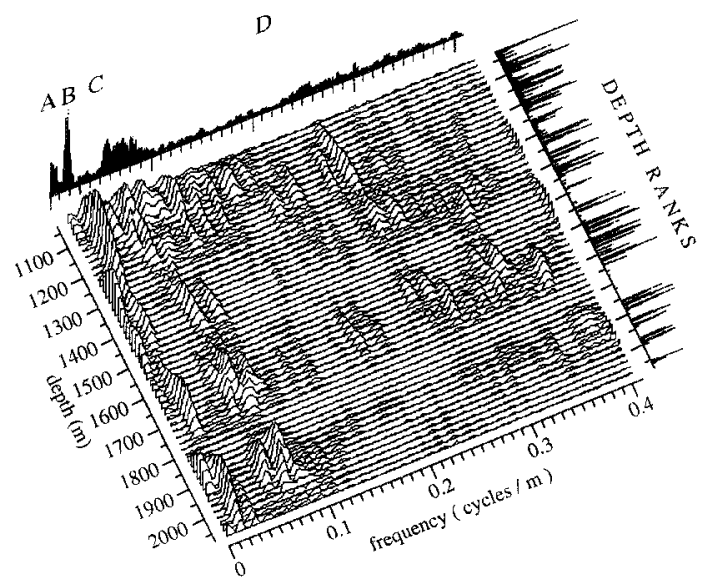

Fig. 11. Joint time-frequency spectrum of interval III. Same abbreviations and parameters as Fig. 9.

cycles). There are no black shales in the NBCP cores through this interval, resulting in a marked decline in the range of depth ranks that translates into an order of magnitude decline in estimated spectral density and a lower signal to noise ratio (Figs. 7 and 8). There is almost no consistent power at higher frequencies (Van Houten cycles) and the statistically significant peaks present are spread out over a broad range. This is the poorest of the NBCP spectral estimates. Nonetheless, there are well-defined concentrations of power in the short modulating and McLaughlin cycles, with two significant peaks corresponding to those at 0.050 and 0.077 cycles $/ \mathrm{m}$ ( 19.9 and $13.0 \mathrm{~m} /$ cycle) through most of the spectrogram, and the McLaughlin cycle tracing through the entire interval at 0.017 cycles $/ \mathrm{m}$ ( $58.1 \mathrm{~m} /$ cycle) (Fig. 12).

The transition between intervals III and IV corresponds to an almost complete disappearance of Van Houten cycle type IV and the dominance of type $\mathrm{V}$ reflecting a switch to an alternation of shallow lakes and vegetated mudflats (Smoot and Olsen, 1994).

\section{Age model}

We have used two independent methods over very different stratigraphic length scales to develop 


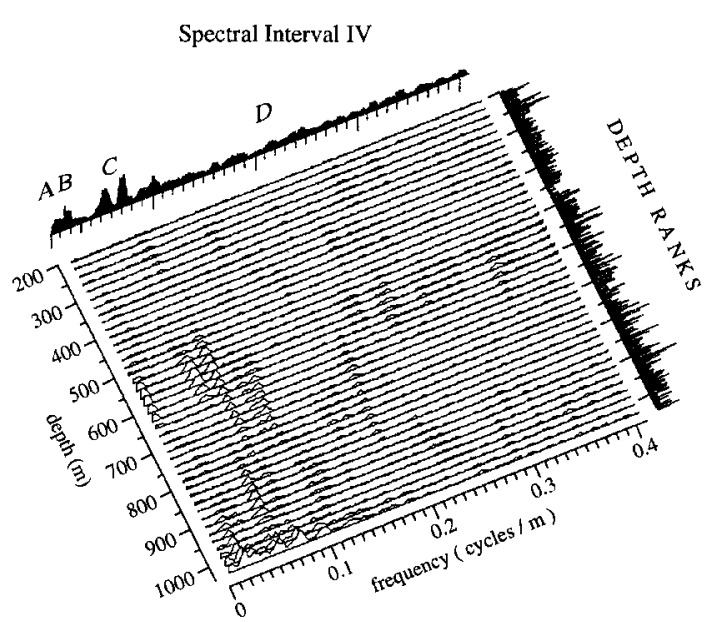

Fig. 12. Joint time-frequency spectrum of interval IV. Same abbreviations and parameters as Fig. 9.

an age model for the NBCP cores. These are: (1) geologic time scales, with biostratigraphic correlation to published radiometric dates; and (2) varve calibration of sedimentation rates. Both methods give very similar results.

\subsection{Geologic time scales}

Both the spectral estimates and the spectrograms show a varying expression of basically the same hierarchical pattern of cycles, implying a continuity of cause under slightly changing accumulation rates. The only known causal mechanism that is capable of producing such a consistent hierarchical pattern of cycles is astronomical forcing of climate. It would be desirable to examine the periodicity of the cycles in time in the NBCP cores by calibration of accumulation rates using direct radiometric dates from the cores themselves, or to use the magnetic reversal pattern from the cores (e.g. Kent et al., 1995) to correlate with a standard marine magnetic anomaly time scale. Neither are possible, however, because there is only one interval in the Newark basin (the basalt formations and coeval intrusions) from which radiometric dates have been obtained, and there is no intact oceanic crust of pre-Jurassic age (Kent and Gradstein, 1986). Therefore, although far from satisfactory, biostratigraphic ties to published radiometrically calibrated geological time scales must suffice as the main current means of constraining the duration of the cycles revealed by spectral analysis.

There are three biostratigraphically defined boundaries in the Newark section which can be correlated to existing time scales: the TriassicJurassic boundary, the Norian-Rhaetian boundary, and the Carnian-Norian boundary (Fig. 2). These boundaries, all in the Passaic Formation, are based primarily on pollen and spore assemblages correlated to the European standard sequences (Cornet and Olsen, 1985; Cornet, 1977, 1993) and are supported by vertebrate remains (Olsen and Sues, 1986; Lucas and Huber, 1994). The Triassic-Jurassic boundary in the Newark basin is known to lie within a single Van Houten cycle in the lower Exeter Member and the lithological units containing the boundary are correlative basin wide (Fowell and Olsen, 1993). The Rhaetian-Norian transition occurs within an interval of two McLaughlin cycles (member FF and Cedar Grove Member), and the CarnianNorian boundary lies within an interval of three McLaughlin cycles (member $\mathrm{C}$ through Graters Member). The Triassic-Jurassic is probably the most reliable and the Rhaetian-Norian boundary is the least reliable of these paleontologically defined boundaries.

Assuming that all the McLaughlin cycles were caused by the same periodic process, we can estimate their duration and use them to provide a basis of assessing the relative amount of time between the Newark biostratigraphic boundaries. To count the McLaughlin cycles objectively, we filtered the composite depth rank curve with a zero-phase bandpass filter with the minimum and maximum frequencies based on the results of the spectral analysis (Fig. 2). This produces a smooth curve that is directly comparable to a smoothed curve of the original depth rank data and the member-level stratigraphy of the section (Fig. 2), which is conceptually based on the McLaughlin cycles. Thus, there are $53 \mathrm{McLaughlin}$ cycles based on the filtered depth rank series and there are 53 members in the Lockatong and Passaic formations. The biostratigraphic boundaries are correlated to published time scales using least squares linear regression, and the slope of the regression line is then in years/cycle (Fig. 13; Tables 2 and 3 ). 


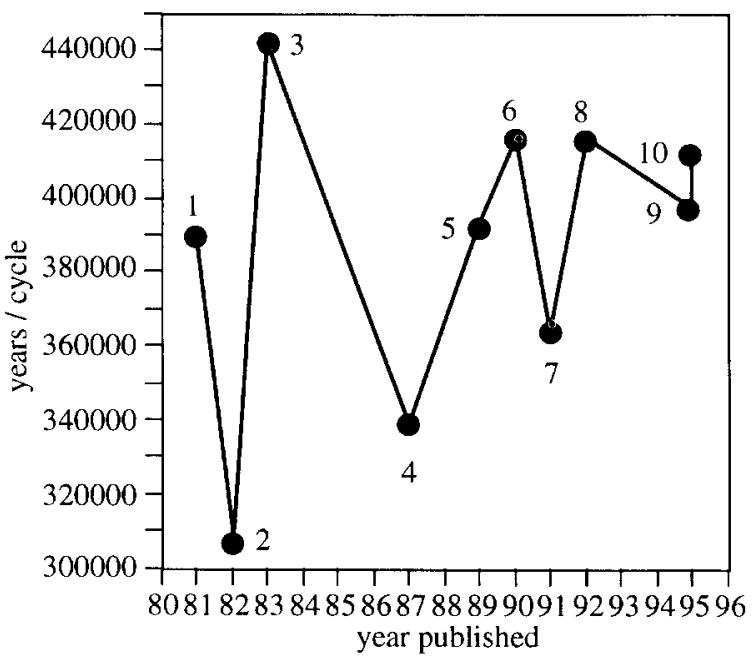

Fig. 13. Calibration of the duration of the McLaughlin cycle based on paleontological correlations with recently published time scales. For references (1-10 in figure) see Table 3.

The most recent detailed time scale is that of Gradstein et al. (1995). Correlation of their three boundary ages with the Newark basin section yields a duration of $397.7 \pm 58.5$ k.y. per McLaughlin cycle (Table 3). Nine other time scales published over the last 14 years (Table 3 ) produce periods for the McLaughlin cycle that range from $308 \mathrm{ky} /$ cycle to $442 \mathrm{k} . \mathrm{y}$./cycle, with the more recent time scales converging on a value close to 400 k.y./cycle (Fig. 13). As previously proposed (Van Houten, 1962, 1964, 1969; Olsen, 1986), these values correspond well to the period of the $\sim 400$ ky cycle of astronomical theory $(412,885 \mathrm{yr} /$ cycle; Berger et al., 1992). The climatic expression of this cycle is a modulation of the Earth's precession by Venus and Jupiter which should make it the most stable of the orbital cycles over geological time (Berger et al., 1992; Laskar, 1990). We believe the variation in assessments of the duration of the McLaughlin cycle in the Newark section based on different published time scale reflects uncertainty in the geologic time scales, not uncertainty in the duration in the cycle itself.

Accepting that the McLaughlin cycle is the 412.9 k.y. cycle, a more continuous accumulation rate curve can be constructed for the entire Triassic age lacustrine (Fig. 14). The accumulation rates
Table 2

Significant periods in depth rank from spectral intervals I-IV from Fig. 8. Significant periods in depth rank from spectral intervals I-IV (letters refer to labeled spectral peaks in Fig. 7)

\begin{tabular}{|c|c|c|c|c|c|}
\hline \multicolumn{3}{|c|}{ Spectral interval } & \multirow[b]{2}{*}{ III } & \multirow[b]{3}{*}{$\mathrm{m}$} & \multirow[b]{3}{*}{ k.y. } \\
\hline \multirow[t]{2}{*}{ I } & & & & & \\
\hline & $\mathrm{m}$ & k.y. & & & \\
\hline $\mathrm{a}$ & 73.9 & 412.9 & $a$ & 258.1 & 1856.6 \\
\hline b & 22.8 & 127.4 & $\mathrm{~b}$ & 57.4 & $412.9^{2}$ \\
\hline c & 17.4 & 97.2 & $c$ & 17.5 & 125.9 \\
\hline $\mathrm{d}$ & 5.5 & 30.7 & $\mathrm{~d}$ & 13.2 & $95.0^{1}$ \\
\hline e & 4.6 & 25.7 & $\mathrm{e}$ & 5.5 & 39.6 \\
\hline \multirow[t]{5}{*}{ f } & 3.9 & 21.8 & $\mathrm{f}$ & 4.0 & 28.8 \\
\hline & & & $\mathrm{g}$ & 3.4 & $24.5^{1}$ \\
\hline & & & $\mathrm{h}$ & 3.2 & $23.0^{1}$ \\
\hline & & & i & 2.9 & $20.9^{1}$ \\
\hline & & & $\mathrm{j}$ & 2.7 & 19.4 \\
\hline \multicolumn{3}{|l|}{ II } & \multicolumn{3}{|l|}{ IV } \\
\hline $\mathrm{a}$ & 85.1 & 412.9 & $a$ & 304.8 & $2166.1^{2}$ \\
\hline$b$ & 23.7 & 115.0 & $\mathrm{~b}$ & 58.1 & $412.9^{1}$ \\
\hline $\mathrm{c}$ & 21.2 & 102.9 & $\mathrm{c}$ & 19.9 & $141.4^{1}$ \\
\hline $\mathrm{d}$ & 8.5 & $41.2^{1}$ & $\mathrm{~d}$ & 13.0 & 92.4 \\
\hline e & 6.2 & 30.1 & $\mathrm{e}$ & 11.1 & $78.9^{1}$ \\
\hline f & 5.3 & $25.7^{1}$ & $\mathrm{f}$ & 9.4 & 66.8 \\
\hline $\mathrm{g}$ & 4.8 & 23.3 & $\mathrm{~g}$ & 5.2 & $37.0^{1}$ \\
\hline $\mathrm{h}$ & 4.5 & 21.8 & $\mathrm{~h}$ & 4.5 & 32.0 \\
\hline i & 4.2 & 20.4 & $\mathrm{i}$ & 4.1 & 29.1 \\
\hline \multirow[t]{3}{*}{$\mathrm{j}$} & 3.9 & 18.9 & $\mathrm{j}$ & 3.0 & 21.3 \\
\hline & & & $\mathrm{k}$ & 2.8 & 19.9 \\
\hline & & & 1 & 1.7 & $12.1^{1}$ \\
\hline
\end{tabular}

${ }^{1}$ Frequencies that are averages of more than one significant line. ${ }^{2}$ Passes test of significance only at the $p=0.15$ level, but is an important element of the data

calculated from the slopes of the straight line segments $(0.1390-0.2061 \mathrm{~mm} / \mathrm{yr}) \quad$ correspond very closely to the thickness periods revealed by the multitaper spectrum estimates $(0.1422-$ $0.2025 \mathrm{~mm} / \mathrm{yr}$ ) (Fig. 8; Table 4). This comparison provides a check on the consistency of the multitaper spectrum estimates.

\subsection{Varve calibration}

Van Houten (1962, 1964, 1969) and Olsen (1986) estimated the duration of cycles in outcrops of the Lockatong Formation by determining accumulation rate from the average thickness of 
Table 3

Duration of the McLaughlin cycle based on published time scales

\begin{tabular}{|c|c|c|c|c|c|}
\hline $\begin{array}{l}\text { No. from } \\
\text { Fig. } 13\end{array}$ & Author & $\begin{array}{l}\text { Triassic- } \\
\text { Jurassic }\end{array}$ & $\begin{array}{l}\text { Norian-- } \\
\text { Rhaetian }\end{array}$ & $\begin{array}{l}\text { Carnian- } \\
\text { Norian }\end{array}$ & $\begin{array}{l}\text { k.y./ } \\
\text { cycle }^{1}\end{array}$ \\
\hline 1 & Webb, 1981 & 200.0 & & 215.0 & 389.6 \\
\hline 2 & Harland et al., 1982 & 213.0 & 219.0 & 225.0 & $307.8 \pm 108.2$ \\
\hline 3 & Palmer et al., 1983 & 208.0 & & 225.0 & $441.6 \pm 167.0$ \\
\hline 4 & Haq et al., 1987 & 210.0 & 215.0 & 223.0 & 338.4 \\
\hline 5 & Cowie et al., 1989 & 205.0 & 210.0 & 220.0 & 393.1 \\
\hline 6 & Harland et al., 1990 & 208.0 & 209.5 & 223.4 & $415.7 \pm 117.7$ \\
\hline 7 & Menning, 1991 & 208.0 & & 222.0 & 363.6 \\
\hline 8 & Odin and Odin, 1992 & 204.0 & & 220.0 & $415.6 \pm 77.1$ \\
\hline 9 & Gradstein et al., 1995 & 205.7 & 209.6 & 220.7 & $396.7 \pm 58.5$ \\
\hline \multirow[t]{2}{*}{10} & Gallet et al., 1995 & 205.0 & 210.0 & 220.7 & 412.2 \\
\hline & Cycle number & 1 & 16.5 & 39.5 & \\
\hline
\end{tabular}

${ }^{1}$ Error estimate compounded using root mean square method where error estimates were supplied in the original source.

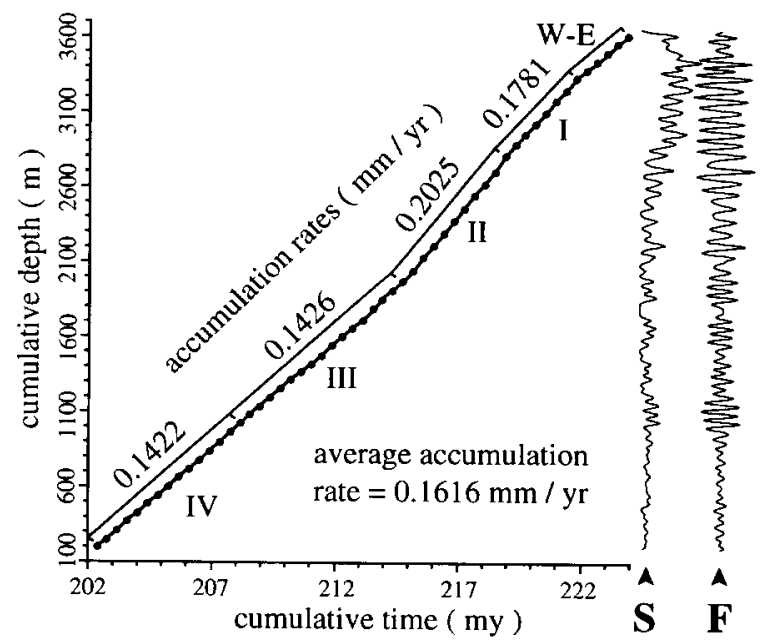

Fig. 14. Plot of cumulative time based on McLaughlin cycle number against cumulative depth in the composite core section (Fig. 2). 202.0 Ma is our age estimate for the Orange Mountain Basalt and 202.4 is taken as the peak of McLaughlin cycle 1 (Exeter Member of Passaic Formation). $S$ is the depth rank curve in Fig. 2 smoothed with a $60 \mathrm{ft}(18.3 \mathrm{~m})$ triangular moving window. $F$ is the filtered depth rank curve from Fig. 2. The average accumulation rate $(0.1616 \mathrm{~mm} / \mathrm{yr})$ is the slope of the least squares regression line through all of the points; the accumulation rates for spectral intervals I-IV are the slopes of the least squares regression lines though those segments. W-E are points representing the Wilburtha through Ewing Creek members of the Lockatong Formation, which are transitional from the underlying fluvial Stockton Formation. organic-carbonate couplets in the high depth rank (4-5) portions of division 2 of Van Houten cycles, assuming them to be varves. These accumulation rates suggested periods of $\sim 20,000 \mathrm{yr}$ for the Van Houten cycle. Preliminary analysis of similar "varved" intervals in the NBCP cores (e.g., Fig. 15) yields accumulation rates in line with those estimated by correlation to geological time scales (Table 4). This is a completely independent, yet direct means of assessing the time scale for the NBCP cores and suggests an average sedimentation rate $(0.1611 \mathrm{~mm} / \mathrm{yr})$ very similar to that derived from assuming a 412.9 k.y. duration of the McLaughlin cycle $(0.1662-0.1616 \mathrm{~mm} / \mathrm{yr})$. It is important to recall, however, that units of rank 5 comprise only a very small fraction of the thickness of the total section. The assessments of the duration of the sedimentary cycles are nevertheless consistent from the scale of the entire lacustrine section ( $22 \mathrm{~m} . \mathrm{y}$.) correlated to radiometric time scales to the scale of the varve $(1 \mathrm{yr})$ measured directly.

\section{Comparison of NBCP spectral analysis with astronomical theory}

It is not yet possible to produce an insolation time series for any portion of the Mesozoic because of inherent limitations in the precision of the celestial mechanical constants (Berger, 1977), 
Table 4

Summary of accumulation rates of spectral intervals assessed by different means (all stratigraphic lengths scaled to Rutgers). Estimated accumulation rates of spectral intervals I-IV

\begin{tabular}{|c|c|c|c|c|}
\hline $\begin{array}{l}\text { Spectral } \\
\text { zone }\end{array}$ & $\begin{array}{l}\text { Spectrum estimates } \\
\text { calibrated with } \\
412.9 \text { k.y. for } \\
\text { McLaughlin Cycle } \\
(\mathrm{mm} / \mathrm{yr})\end{array}$ & $\begin{array}{l}\text { McLaughlin Cycle } \\
\text { counted assuming } \\
412.9 \text { k.y. duration } \\
\text { in Fig. } 17 \\
(\mathrm{~mm} / \mathrm{yr})\end{array}$ & $\begin{array}{l}\text { Varve } \\
\text { calibration } \\
(\mathrm{mm} / \mathrm{yr})\end{array}$ & $\begin{array}{l}\text { Correlation with } \\
\text { climatic precession } \\
\text { spectrum }^{1}\end{array}$ \\
\hline I & 0.1790 & 0.1781 & $0.1808^{2}$ & 0.2028 \\
\hline II & 0.2061 & 0.2025 & - & 0.2048 \\
\hline III & 0.1390 & 0.1426 & $0.1404^{3}$ & 0.1390 \\
\hline IV & 0.1407 & 0.1422 & - & 0.1497 \\
\hline
\end{tabular}

${ }^{1}$ Method of calculation is the same as for Fig. 18 (long modulating cycle omitted).

${ }^{2} n=78$ couplets, from Skunk Hollow Member of Lockatong Formation ( $1714 \mathrm{ft}$ core depth, Nursery no. 1)

${ }^{3} n=113$ couplets, from Ukrainian Member of Passaic Formation (259.9 ft core depth, Somerset no. 2; see Fig. 15).

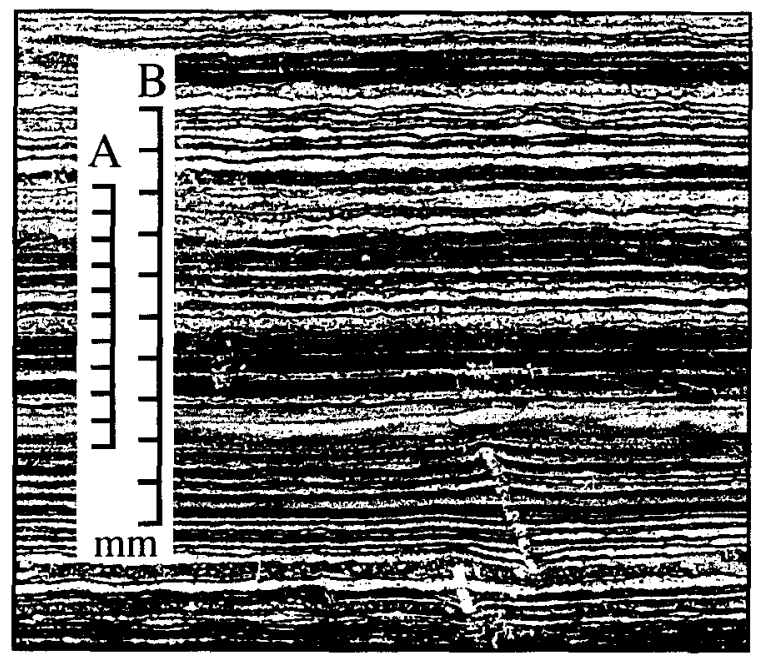

Fig. 15. Photograph of microlaminated mudstone (depth rank 5) showing organic-rich/carbonate-rich couplets interpreted as varves ( $259.9 \mathrm{ft}$, Somerset no. 2 core). Scale $\mathrm{A}$ is in the original dimensions. Scale B has been enlarged by $159 \%$ to account for the $45.6^{\circ}$ cut of the face to bedding and a conversion factor of 0.8812 that puts scale $B$ in the dimensions of the Rutgers core, the composite depth rank section, and the spectrum estimates (factor from Olsen et al., 1995). Couplets were counted using a binocular microscope with a camera lucida drawing tube attachment.

uncertainties in long term drift in the recession rate of the moon (Walker and Zahnle, 1986; Sonnet et al., 1988), and small effects of the chaotic behavior of planetary orbits (Laskar, 1990; Berger et al., 1992). It is possible, however, to make comparisons in the frequency domain between the spectra of climatic precession for the late Neogene with those of the NBCP cores (e.g., Hays et al., 1976).

Comparison of the predictions of celestial mechanics for climate spectra for the recent past and with the Triassic reveals some striking similarities and some differences. We produce a summed spectrum estimate for the Lockatong and Passaic formations by scaling the spectral estimates from each interval, using the estimate for spectral interval $I$ as the standard. The spectral estimates are normalized to the same McLaughlin cycle frequency and total spectral density and averaged (Fig. 16, top). The result looks very similar to the spectrum estimate for interval I (Fig. 16, middle), and this similarity is a reflection of the strong consistency in these spectral estimates.

Assuming that the McLaughlin cycle is indeed the 412.9 k.y. cycle, all of the predicted precessionrelated cycles appear to be present in the NBCP cores. The two modes of the $\sim 20,000$ year cycle of climatic precession are present as the Van Houten cycles; the two modes of the $\sim 100,000$ year eccentricity are represented by the short modulating cycles; the single, and well defined, peak of the 412.9 k.y. eccentricity cycle is the McLaughlin cycle, and the $\sim 2$ m.y. year eccentricity cycle is identifiable as the long modulating cycle. The consistent presence of the two peaks in the frequency band of the short modulating cycle $(\sim 100 \mathrm{k} . \mathrm{y}$.$) is a special prediction of celestial$ mechanics that has long been anticipated (Berger, 

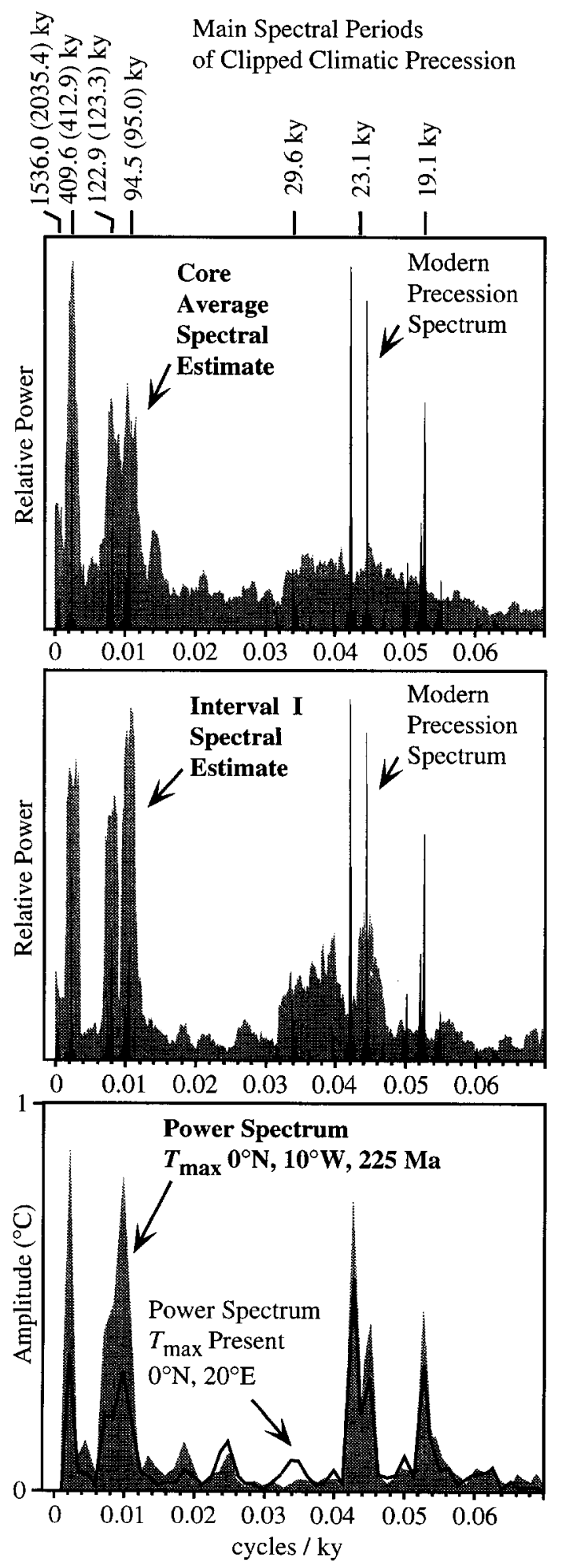

1977) but rarely seen in geological records. In addition, it is interesting to note that where two spectral peaks are resolved in the multitaper spectral estimates, they are also in the correct (or modern) ratios of relative amplitude with the higher frequency peak being higher in amplitude than the lower frequency peak (Fig. 8).

The average spectrum estimate and that from spectral interval I also show strong similarities to the predictions of the energy balance model of tropical climate of Crowley et al. (1992) (Fig. 16, bottom). This is important because this model produces an index of maximum heating that is closely related to the presumed mechanism of precipitation variations in the tropics today as well as in Triassic Pangaea.

A comparison of the detailed structure of the joint space-frequency spectrograms of the depth ranks of spectral interval I to that of an equal length spectrogram of a time series of clipped climatic precession also provides strong evidence of astronomical processes (Fig. 17). Positive values of climatic precession were truncated or clipped at zero to bring out the effect of amplitude modulation in the spectra. Most significant is the cyclical variation with time in the expression of the two zones of high power in the frequency band of the short modulating cycle ( $C$ of Fig. 17). This same kind of variation occurs in the spectrogram of clipped insolation, where it can be thought of as resulting from the interference of two cycles around $19 \mathrm{k} . \mathrm{y}$. This interference produces a beat cycle of about $2 \mathrm{~m} . \mathrm{y}$. in the strength of the average 19 k.y. cycle. Because the $\sim 100$ k.y. cycles are due to interference of two cycles around $23 \mathrm{k} . \mathrm{y}$. with those around 19 k.y., the $\sim 100$ k.y. cycle sees the same beat cycle. That the same kind of variation occurs in the depth rank spectrograms suggests

Fig. 16. Comparison of multitaper spectral estimates of NBCP core average (scaled to Interval II), spectral interval I, power spectrum (FFT) of clipped climatic modern precession (from Berger and Loutre, 1991), and energy balance climate model for maximum temperature for present and Pangaea during the Carnian (Crowley et al., 1992; spectrum truncated at 0.7 cycles/k.y.). All periods are expressed as years (see text for explanation). Identified periods are estimates from the FFT of clipped climatic precession with the correct values for those periods given in parentheses (from Berger and Loutre, 1990). 


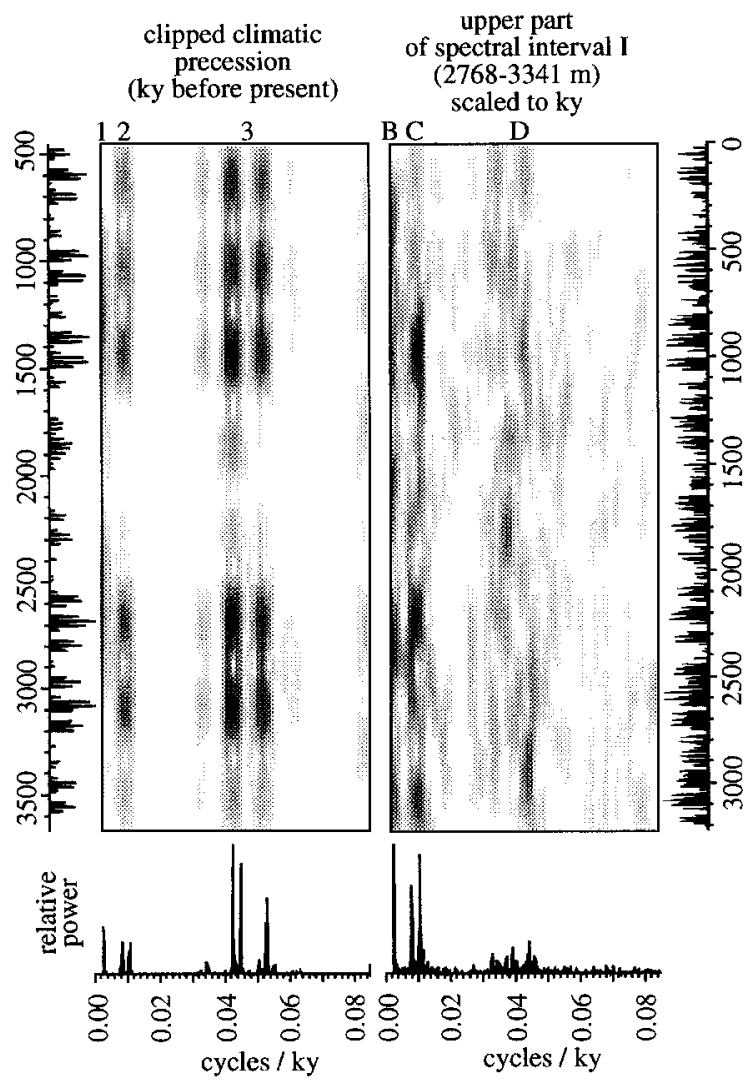

Fig. 17. Comparison of joint time-frequency spectrograms of climatic precession (Berger and Loutre, 1991; positive values clipped at 0.005 to bring out the low frequency amplitude modulation) and depth ranks from spectral interval I scaled to time using the accumulation rate $(0.1781 \mathrm{~mm} / \mathrm{yr})$ from Fig. 14. Abbreviations are: $I=412.9$ k.y. cycle; $2=123.3$ and 95.0 k.y. cycles; $3=23.1$ and 19.1 k.y. cycles; $B=$ McLaughlin cycle, $C=$ short modulating cycles; and $D=$ Van Houten cycles. In both spectrograms $\Delta t$ is $1.5 \mathrm{ky}$, a Hamming window with a length of $150 \mathrm{k.y}$. was used, and the spectrograms were computed using a short time Fourier transform in Lab View ${ }^{\mathrm{TM}}$ (National Instruments). Spectra below joint time-frequency spectrograms are FFTs.

that the same kind of interference processes are operating.

Berger et al. (1992) suggest that while the main periods of climatic precession presently average 19 k.y. and 23 k.y., in the Triassic-Early Jurassic those periods should be about $18 \mathrm{k} . \mathrm{y}$. and 21.5 k.y., respectively. Unfortunately, the calculation of these periods is dependent on estimates of both the recession rate of the moon and length of the day, both of which are uncertain over a fairly large range over the history of the Earth. It is, in fact, plausible that the climatic precession cycles were not as different from present day values as often assumed based on the day length and recession rates in Williams (1991).

Change in the modulation of climatic precession by the "eccentricity" cycles is in any case expected to be small in relative magnitude (Berger et al., 1992), although perhaps just discernible for the longest of the periods (i.e. the $\sim 2 \mathrm{~m}$.y. cycle) compared to modern values. The most stable of all of the planetary fundamental frequencies should be that of $g_{5}$, related to Jupiter. The fundamental frequency $g_{5}$ enters into the calculation of the 412.9 k.y. "eccentricity" cycle, along with $\mathrm{g}_{2}$ (Venus) (Berger et al., 1992; Laskar, 1990). The 412.9 k.y. cycle in the Triassic should thus be essentially unchanged from its present value. This is why we use this cycle to calibrate the spectra rather than the Van Houten cycles. Scaling all of the periods to presumed periods of Van Houten cycles, for example, would result in a $11 \%$ reduction in the period of the $\sim 400 \mathrm{k} . \mathrm{y}$. cycle which is far beyond even a liberal assessment of the needed influence of planetary chaos on the eccentricity cycle.

We can nevertheless relax the assumption that the McLaughlin cycle has exactly a period of 412.9 k.y., and simply assume that there is a general correspondence between the major peaks in the spectral estimates of the NBCP climate record and those of a spectral estimate based on Neogene climatic precession (Fig. 18). Peaks in the McLaughlin frequency band are well defined in all the spectra, as are most of those of the short modulating cycle. Peaks in the Van Houten cycle frequency band correlating with the $30 \mathrm{k} . \mathrm{y} ., 23$ k.y., and 19 k.y. peaks in the astronomical spectrum were chosen on the basis of their consistency through changing stratigraphic position in the detailed spectrograms (Figs. 9-12). Based on any published time scale the McLaughlin cycle must correspond to the $\sim 400 \mathrm{k} . \mathrm{y}$. astronomical cycle and the two peaks band representing the short modulating cycle should therefore correspond to the $125 \mathrm{k} . \mathrm{y}$. and $95 \mathrm{k} . \mathrm{y}$. peaks in astronomical forcing. The geologic time scales would 

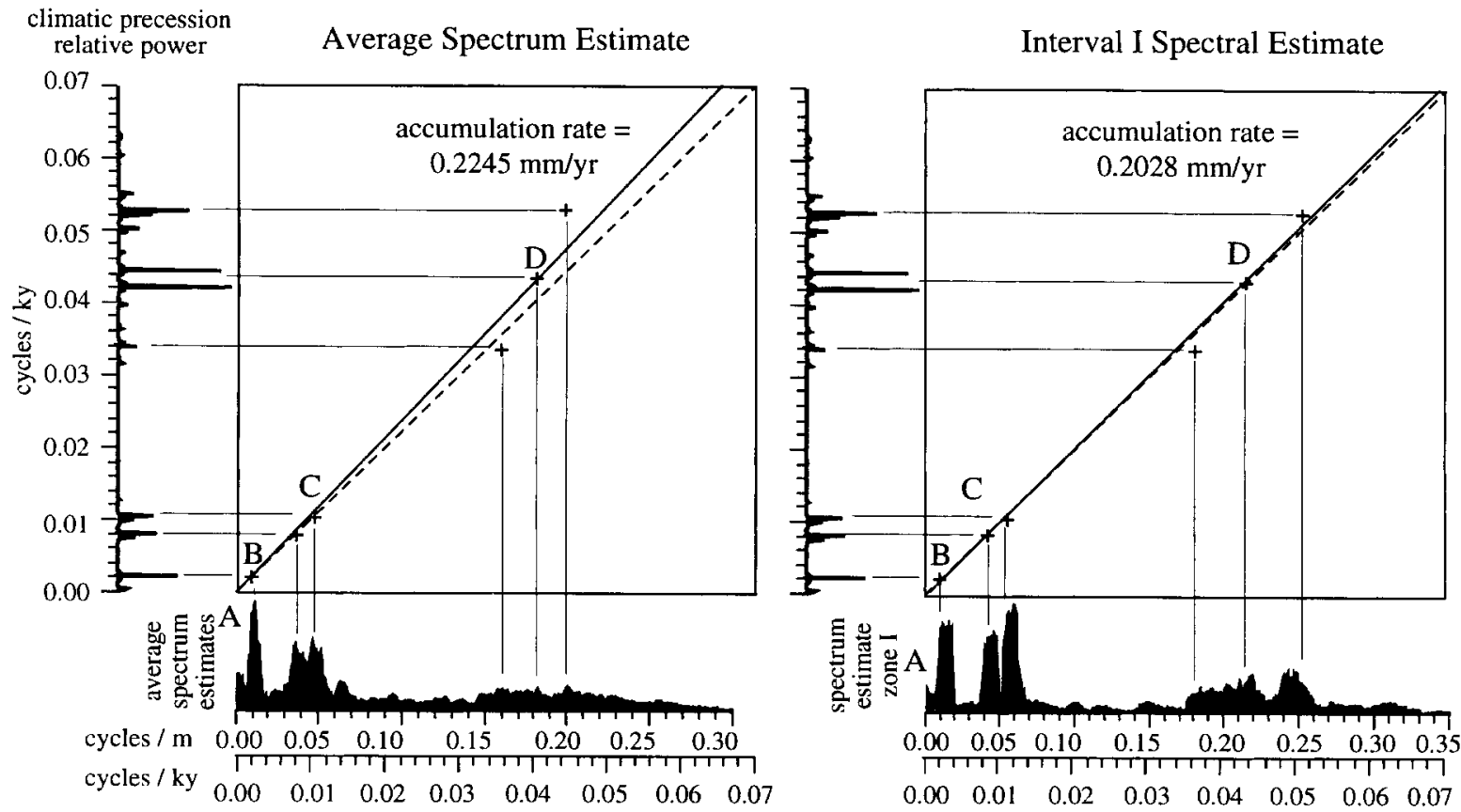

Fig. 18. Examples of cross plots of FFT spectrum of climatic precession (positive values clipped at 0.005 to bring out the low frequency amplitude modulation) with the average multiple-window spectrum estimate of all of the spectral intervals and the multiple-window spectrum estimate of spectral interval I (see Table 4). Note that the average spectral estimate is scaled to spectral interval II. Data for climatic precession from (Berger and Loutre, 1991).

have to be off by an implausible degree to associate the spectral peaks in a different way to known orbital forcing periods; for example, the Late Triassic would need to have a duration of roughly $120 \mathrm{~m} . \mathrm{y}$. instead $30 \mathrm{~m} . \mathrm{y}$. to associate the short modulating cycle to the 412.9 k.y. astronomical cycle instead of the $\sim 100 \mathrm{k} . \mathrm{y}$. cycle. Making the obvious correlation of spectral peaks, the slope of the regression line in these graphs is the mean accumulation rate. The rates correspond well to those estimated from the filtered depth rank curve, but tend to be a bit higher (Table 4). Although, as discussed above, the most stable astronomical period should be the $\sim 400 \mathrm{k} . y$. cycle, this method is not reliant on any specific astronomical frequency remaining unchanged for 200 million years.

The most striking differences with the predictions of celestial mechanics are the slightly lower frequencies (longer periods) of the presumed climatic precession cycles (Van Houten cycles) and the relatively very high power of the low frequency cycles (long modulating, McLaughlin, and short modulating cycles) in the Late Triassic lacustrine record. Assuming that the McLaughlin cycle is 412.9 k.y. in period, Van Houten cycles tend to have periods averaging around $25 \mathrm{k} . \mathrm{y}$. and $21 \mathrm{k} . \mathrm{y}$. The cycles of climatic precession presently average $23 \mathrm{k} . \mathrm{y}$. and 19 k.y., respectively, and according to theory based on the recession of the moon through time (Walker and Zahnle, 1986; Berger et al., 1992; Sonnet et al., 1988), these periods should be shorter in the Triassic, not longer. It is hard to see how any reasonable change in orbital parameters can account for this difference. If we accept the astronomical origin of the NBCP cycles, then at least some of this discrepancy is likely due to frequency modulation of accumulation rate in the climatic precession range. While random variations or noise in the accumulation rate could account for the relative increase in power in the low frequency range, some of the high power in the low frequencies as well as the shift to lower frequency of the Van Houten cycles may be explicable by a positive dependence of accumulation rate on depth rank 
amplitude. In other words, the deeper the lakes, the higher the accumulation rate would be in the frequency band of the Van Houten cycles. Crowley et al. (1992) suggest that the large amounts of power in the low (eccentricity) frequencies in paleoclimatic data in equatorial areas (specifically Triassic Jurassic data) are due to a "doubling" and "rectification" of the climatic precession cycle by the twice per cycle migration of the zone of maximum heating across the equator. However, a signature of this process is the appearance of significant power at twice the climatic precessional frequencies, which we do not see in the NBCP cores (Fig. 16). However, a pattern matching Crowley's predictions may be apparent farther south in coeval Triassic lacustrine deposits closer to the paleoequator (Olsen and Johansson, 1994).

A surprising result of the joint-space-frequency analysis (Fig. 7) and the spectrum estimates (Fig. 8) is the relatively strong appearance of a cycle of about $2 \mathrm{~m} . \mathrm{y}$.- the long modulating cycle. This is a prediction of celestial mechanics (Berger and Loutre, 1990) usually omitted from discussions of Milankovitch climate forcing (with some exceptions, e.g., Matthews and Frohlich, 1991). This cycle shows up clearly as the rhythmic pulsations of spectral power in the joint-spacefrequency analysis (Figs. 7 and 9-12) and as a peak in the spectrum estimates of the spectral intervals (Fig. 8). A more detailed discussion of this cycle, as well as the FM modulation, will be presented elsewhere (Olsen and Kent, in prep.).

Despite the clear importance of precession related astronomical forcing in the Newark lake record, there is little indication of systematic forcing in the obliquity frequency range (expected periods close to 41 or $54 \mathrm{k} . \mathrm{y}$.). Only rarely is there any significant power in this frequency band. This is consistent with relatively local forcing of climate in the equatorial regions. The lack of evidence for forcing in the obliquity range also suggests rather weak linkages with the climate systems of higher latitudes where the obliquity cycles should be more important.

\section{Origin of the lake level signal}

The cyclicity seen in the NBCP cores is clearly due to the effects of lake-level variation on sedi- ment properties. The high frequency lake level cycles that produced the Van Houten cycles and the hierarchy of modulating cycles are very hard to explain by changes in the relationship between the sediment surface and the drainage outlet position (Schlische and Olsen, 1990). Precipitation and evaporation changes are thus the most effective agent for the control of lake depth.

A number of authors (Crowley et al., 1992; Crowley and North, 1991) have argued that Newark lake levels were controlled by Milankovitch modulation of the monsoon systems of Pangaea. This involves the type of movement and changes in the intensity of the area of maximum heating and wind convergence that ultimately results in seasonal precipitation variation as in central Africa today (Webster, 1985; Hastenrath, 1985; COHMAP, 1988). The origin of the extreme variation of the lake levels documented in the NBCP cores is most likely due to the immense continentality of Pangaea and concomitantly large land-sea contrast (Crowley et al., 1992; Kutzbach, 1994; Kutzbach and Gallimore, 1988; Hay et al., 1982; Crowley and North, 1991). According to our interpretation of the model of Crowley et al. (1992), Newark basin lakes would likely have experienced a monsoonal climate with a strong late spring rainy period and a very weak late fall rainy period. The most intense rainy seasons, and the deepest lakes, would occur when the precession cycle results in perihelion in northern hemisphere summer during times of maximum eccentricity of the Earth's orbit. Correspondingly, the weakest rainy seasons and lowest lake levels would occur when perihelion was in the southern hemisphere summer during times of minimum eccentricity. This pattern is similar to that seen in the late Quaternary of Africa (Yan and Petit-Maire, 1994; Street-Perrott et al,, 1995); however, there are no long term records from Africa to document the full range of orbital forcing of continental climate in the more recent geologic past.

Long term drift in the amplitude of depth ranks over the entire NBCP core section (Fig. 2) is probably due to a combination of tectonic changes modifying the area of the depositional surface (Schlische and Olsen, 1990; Smoot and Olsen, 1994), the northward drift of Pangaea across cli- 
mate belts (Kent et al., 1995), changing orography and ocean distribution (Manspeizer, 1994) and perhaps non-Milankovitch global climate change. The large scale changes in accumulation rates, such as those between the main spectral intervals, are most likely due to tectonic changes effecting the area of the basin (Schlische and Olsen, 1990), the rate of subsidence, and the relative relief of watersheds. Higher frequency changes in accumulation rate, such as those within spectral intervals II, III, and IV, and the asymmetry of facies seen within Van Houten cycles themselves, may be due to temporary, but fairly large scale disequilibria between the supply of sediments by rivers and its storage in deltas, shoreline areas, and pediments similar to what is seen in sea level oscillation cycles (Einsele and Bayer, 1991). There is also cyclical change in accumulation rate at the astronomical frequencies that could be to be due to climaterelated changes in weathering and sediment supply rates (Olsen and Kent, in prep.).

\section{Conclusions}

The Triassic represents one of the extreme end members of Earth's geography and climate. There was only one major continent, Pangaea, more or less symmetrically disposed about the equator but extending from pole to pole, and a complementary super-ocean, Panthalassa (Fig. 1). During the Late Triassic, the Newark basin was accumulating lacustrine sediment within about $10^{\circ} \mathrm{N}$ of the equator in the interior of Pangaea. Cores recovered from this basin by the Newark Basin Coring Project record astronomically controlled changes in precipitation and evaporation in this region over an interval of more than 22 million years. Based on Fourier and joint space-frequency analyses, the full range of precession-related periods of lake level change are present, including the two peaks of the $\sim 20,000$ year cycle of climatic precession, the two peaks of the $\sim 100,000$ year eccentricity cycle, the single peak of the 412,900 year eccentricity cycle, as well as the $\sim 2,000,000$ year eccentricity cycle. Consistently strong in amplitude through the entire core lacustrine sequence are the two modal periods of the $\sim 100,000$ year eccentric- ity cycle and the single mode of the 412,900 year eccentricity cycle, which are specific predictions of the astronomical theory of climate change.

The Triassic was a "hot house" world, with no evidence of polar ice (Frakes and Francis, 1988), with extensive vegetation in polar regions (Cornet and Olsen, 1985; Robinson, 1973), and most probably with elevated $\mathrm{CO}_{2}$ relative to today (Berner, 1991). The large amount of power in the low frequency lake level cycles, therefore, probably was not due to large scale interactions of tropical climate with ice sheets. Absence of obliquity cycles in the Newark lake record is further evidence of a lack of direct linkages to high latitude climate systems. It seems likely to us that the precessionrelated cycles in precipitation (including the powerful effect of the eccentricity cycles on precession) are a consistent feature of tropical climate during most times in Earth history (e.g., Herbert and D'Hondt, 1990).

\section{Acknowledgments}

We thank all of those associated with the acquisition of the cores, especially Amoco Production Company and the land owners. We thank Gerard Bond, Sarah Fowell, David Goldberg, Annika K. Johansson, Michelle Kominz, Peter $\mathbf{M}$. LeTourneau, Peter deMenocal, and David Reynolds for aid in many parts of the production and review of the manuscript and analysis. We also thank Timothy Herbert, John Kutzbach, and Finn Surlyk for their very helpful reviews and suggestions.

We gratefully acknowledge support by the National Science Foundation, Continental Dynamics Program (EAR 89-16726) and Climate Dynamics Program (ATM93-17227). This is LDEO contribution no. 5500.

\section{References}

Baker, G.S., 1994. An examination of Triassic cyclostratigraphy in the Newark basin from shallow seismic profiles and geophysical logs. Thesis. Lehigh Univ., $145 \mathrm{pp}$.

Berger, A., Loutre, M.F. and Laskar, J., 1992. Stability of the 
astronomical frequencies over Earth's history for paleoclimate studies. Science, 255: 560-566.

Berger, A., 1977. Support for the astronomical theory of climate change. Nature, 269: 44-45.

Berger, A. and Loutre, F.M., 1990. Origine de fréquences des élements astronomiques intervenant dans le calcul de l'insolation. Bull. Acad. R. Belg., 1-3: 45-106.

Berger, A. and Loutre, M.F., 1991. Insolation values for the climate of the last 10 million years. Quat. Sci. Rev., 10: 297-317.

Berner, R.A., 1991. A model for atmospheric $\mathrm{CO}_{2}$ over Phanerozoic time. Am. J. Sci., 291: 339-376.

Cohen, C., 1992. Introduction: A primer on time-frequency analysis. In: B. Boashash (Editor), Time-Frequency Signal Analysis. Methods Applic., 3-42.

COHMAP Members, 1988. Climate changes of the last 18,000 years: Observations and model simulations. Science, 241: 1043-1052.

Cornet, B. and Olsen, P.E., 1985, A summary of the biostratigraphy of the Newark Supergroup of eastern North America with comments on early Mesozoic provinciality. In: 3rd Congr. Latinoamer. Paleontol., Mexico, Simp. Sobre Floras Triasico Tardio, Fitogeographia Paleoecologia Mem., pp. 67-81.

Cornet, B., 1977, The palynostratigraphy and age of the Newark Supergroup. Thesis. Penn. State Univ., University Park, 504 pp.

Cornet, B., 1993. Applications and limitations of palynology in age, climatic, and paleoenvironmental analyses of Triassic sequences in North America. In: S.G. Lucas and M. Morales (Editors), The Nonmarine Triassic. New Mex. Mus. Nat. Hist. Sci. Bull., 3: 75-93.

Cowie, J.W. and Bassett, M.G., 1989. Global stratigraphic chart. Int. Union Geol. Sci.

Crowley, T.J., Kim, K.-Y., Mengel, J.G. and Short, D.A., 1992. Modeling 100,000-year climate fluctuations in prePleistocene time series. Science, 255: 705-707.

Crowley, T.J. and North, G.R., 1991. Paleoclimatology. Oxford Univ. Press, 339 pp.

Dunning, G.R. and Hodych, J.D., 1990, U-Pb zircon and baddeleyite age for the Palisade and Gettysburg sills of northeast United States; implications for the age of the Triassic-Jurassic boundary. Geology, 18: 795-798.

Einsele, G. and Bayer, U., 1991. Asymmetry in transgressiveregressive cycles in shallow seas and passive continental margin settings. In: G. Einsele et al, (Editors), Cycles and Events in Stratigraphy. Spinger, Berlin, pp. 660-681.

El Tabakh, M., 1994, Early rift basin deposition: TriassicJurassic sedimentation and subsequent diagenesis in the Newark basin, New Jersey. Thesis. City Univ. New York, 380 pp.

Fowell, S.J., 1993. Palynology of Triassic/Jurassic boundary sections from the Newark Supergroup of Eastern North America: Implications for catastrophic extinction scenarios. Thesis. Columbia Univ., New York, 133 pp.

Fowell, S.J. and Olsen, P.E., 1993, Time-calibration of Triassic/
Jurassic microfloral turnover, eastern North America. Tectonophysics, 222: 361-369.

Frakes, L.A. and Francis, J.E., 1988. A guide to cold polar climates from high-latitude ice rafting in the Cretaceous. Nature, 333: 547-549.

Gallet, Y., Besse, J., Krystyn, L. and Marcoux, J., 1995. Triassic magnetostratigraphy, in press.

Goldberg, D., Reynolds, D., Williams, C., Witte, W.K., Olsen, P.E. and Kent, D.V., 1994. Well logging results from the Newark Rift Basin Coring Project. Sci. Drilling, 4 (4-6): 267-279.

Gradstein, F.M., Agterberg, F.P., Ogg, J.G., Hardenbol, J., Van Veen, P., Thierry, J. and Huang, Z., 1995. A Triassic, Jurassic, and Cretaceous Time Scale. SEPM Spec. Publ., in press.

Haq, B.U., Hardenbol, J. and Vail, P.R., 1988. Mesozoic and Cenozoic chronostratigraphy and cycles of sea-level change. SEPM Spec. Publ., 42: 71-108.

Harland, W.B., Cox, A.V., Craig, L.E., Smith, A.G. and Smith, D.G., 1990. A Geologic Time Scale in 1989. Cambridge Univ. Press, London, 131 pp.

Harland, W.B., Cox, A.V., Llewellyn, P.G., Pickton, C.A.G., Smith, A.G. and Walters, R., 1982. A Geologic Time Scale. Cambridge Univ. Press, London, $131 \mathrm{pp}$.

Hastenrath, S., 1985. Climate and Circulation of the Tropics. Reidel, Dordrecht, 455 pp.

Hay, W.W., Behensky Jr., J.F., Barron, E.J. and Sloan, J.L., 1982. Late Triassic-Liassic paleoclimatology of the protocentral North Atlantic rift system. Palaeogeogr. Palaeoclimatol. Palaeoecol., 40: 13-30.

Hays, J.D., Imbrie, J. and Shackleton, N.J., 1976. Variations in the Earth's orbit: pacemaker of the ice ages. Science, 194: $1121-1132$

Herbert, T.D. and D'Hondt, S.L., 1990. Precessional climate cyclicity in Late Cretaceous-Early Tertiary marine sediments: a high resolution chronometer of Cretaceous-Tertiary boundary events. Earth Planet. Sci. Lett., 99: 263-275.

Kent, D.V. and Gradstein, F.M., 1986. A Jurassic to Recent chronology. In: P.R. Vogt and B.E. Tucholke (Editors), The Western North Atlantic Region (Geol. North America, 3), pp. $45-50$.

Kent, D.V., Olsen, P.E. and Witte, W.K., 1995. Late Triassicearliest Jurassic geomagnetic polarity sequence and paleolatitudes from drill cores in the Newark basin (eastern North America). J. Geophys. Res., 100 (B8): 14, 965-14, 998.

Kutzbach, J.E. and Gallimore, R.G., 1988. Pangaean climates: megamonsoons of the megacontinent. J. Geophys. Res., 94: 3341-3358.

Kutzbach, J.E., 1994. Idealized Pangean climates: Sensitivity to orbital change. In: G.D. Klein (Editor), Pangea: Paleoclimate, Tectonics, and Sedimentation During Accretion, Zenith, and Breakup of a Supercontinent. Geol. Soc. Am. Spec. Pap., 288: 41-55.

Laskar, J., 1990. The chaotic motion of the solar system: a numerical estimate of the size of the chaotic zones. Icarus, 88: 266-291.

Lucas, S.G. and Huber, P., 1994. Revised internal correlation 
of the Newark Supergroup, Eastern United States and Canada. In: S.G. Lucas and M. Morales (Editors), The Nonmarine Triassic. New Mex. Mus. Nat. Hist. Sci. Bull., 3: $311-319$.

Manspeizer, W., 1994. The breakup of Pangea and its impact on climate: Consequences of the Variscan-Alleghenian orogenic collapse. In: G.D. Klein (Editor), Pangea: Paleoclimate, Tectonics, and Sedimentation During Accretion, Zenith, and Breakup of a Supercontinent. Geol. Soc. Am. Spec. Pap., 288: 169-185.

McLaughlin, D.B., 1933. A note on the stratigraphy of the Brunswick Formation (Newark) in Pennsylvania. Mich. Acad. Sci. Arts Lett., 18: 59-74.

McLaughlin, D.B., 1946. Continuity of strata in the Newark Series. Mich. Acad. Sci. Arts Lett., 32: 295-303.

McLaughlin, D.B., 1959, Mesozoic rocks. In: B. Willard et al. (contributors), Geology and Mineral Resources of Bucks County, Pennsylvania. Penn. Geol. Surv. Bull., C-9: 55-114.

Matthews, R.K. and Frohlich, C., 1991. Orbital forcing of low-frequency glacioeustasy. J. Geophys. Res., 96, B4: 6797-6803.

Menning, M., 1991. Rapid subsidence in the Central European Basin during the initial development (Permian-Triassic boundary sequences, 258-240 Ma). Z. Geol. Paläontol., 4 (1): 809-824.

Odin, G.S. and Létolle, R., 1982. The Triassic time scale in 1981. In: G.S. Odin (Editor), Numerical Dating in Stratigraphy. Wiley, New York, pp. 523-533.

Olsen, P.E., 1980a. The latest Triassic and Early Jurassic formations of the Newark basin (eastern North America, Newark Supergroup): Stratigraphy, structure, and correlation. N. J. Acad. Sci. Bull., 25: 25-51.

Olsen, P.E., 1980b. Triassic and Jurassic formations of the Newark basin. In: W. Manspeizer (Editor), Field Studies of New Jersey Geology and Guide to Field Trips, New York State Geol. Assoc. 52d Annu. Meet., Rutgers Univ., Newark, NJ, pp. 2-39.

Olsen, P.E., 1980c. Fossil great lakes of the Newark Supergroup in New Jersey. In: W. Manspeizer (Editor), Field Studies of New Jersey Geology and Guide to Field Trips, New York State Geol. Assoc., 52d Annu. Meet., Rutgers Univ., Newark, NJ, pp. 352-398.

Olsen, P.E., 1986. A 40-million-year lake record of early Mesozoic climatic forcing. Science, 234: 842-848.

Olsen, P.E., 1988. Continuity of strata in the Newark and Hartford Basins of the Newark Supergroup. U.S. Geol. Surv. Bull., 1776: 6-18.

Olsen, P.E., 1990. Tectonic, climatic, and biotic modulation of lacustrine ecosystems: examples from the Newark Supergroup of eastern North America. In: B. Katz (Editor), Lacustrine Basin Exploration: Case Studies and Modern Analogs. Am. Assoc. Pet. Geol. Mem., 50: 209-224.

Olsen, P.E. and Johansson, A.K., 1994. Field guide to Late Triassic tetrapod sites in Virginia and North Carolina (Culpeper, Richmond, and Dan River Basins, Newark Supergroup). In: H.D. Sues and N. Fraser (Editors), In the
Shadow of the Dinosaurs. Cambridge Univ. Press, pp. 408-430.

Olsen, P.E. and Kent, D.V., 1990. Continental Coring of the Newark Rift. EOS, Trans. AGU, 71: 385, 394.

Olsen, P.E. and Kent, D.V., 1996. The importance of the 413 k.y. and 2 m.y. astronomical cycles to climate. In prep.

Olsen, P.E. and Sues, H.-D., 1986. Correlation of the continental Late Triassic and Early Jurassic sediments, and patterns of the Triassic-Jurassic tetrapod transition: In: K. Padian (Editor), The Beginning of the Age of Dinosaurs, Faunal Change Across the Triassic-Jurassic Boundary. Cambridge Univ. Press, New York, pp. 321-351.

Olsen, P.E., Kent, D.V., Cornet, B., Witte, W.K. and Schlische, R.W., 1996. High-resolution stratigraphy of the Newark rift basin (Early Mesozoic, Eastern North America). Geol. Soc. Am. Bull., 108: 40-77.

Palmer, A.R. (compiler), 1983. Decade of North American Geology (DNAG) Geologic Time Scale. Geology, 11: 503-504.

Percival, D.B. and Walden, A.T., 1993. Spectral Analysis for Physical Applications: Multitaper and Conventional Univariate Techniques. Cambridge Univ. Press, 583 pp.

Reynolds, D.J., 1993. Sedimentary basin evolution: tectonic and climatic interaction. Thesis. Columbia Univ., New York, $215 \mathrm{pp}$.

Robinson, P.L., 1973. Paleoclimatology and continental drift. In: D.H. Tarling and S.K. Runcorn (Editors), Implications of Continental Drift to the Earth Sciences. Academic Press, London, 1, pp. 451-476.

Schlische, R.W., 1992. Structural and stratigraphic development of the Newark extensional basin, eastern North America; evidence for the growth of the basin and its bounding structures. Geol. Soc. Am. Bull., 104: 1246-1263.

Schlische, R.W. and Olsen, P.E., 1990. Quantitative filling models for continental extensional basins with applications to the early Mesozoic rifts of eastern North America. J. Geol., 98: 135-155.

Short, D.A., Mengel, J.G., Crowley, T.J., Hyde, W.T. and North, G.R., 1991. Filtering of Milankovitch cycles by Earth's geography. Quat. Res., 35: 157-173.

Smoot, J.P., 1991. Sedimentary facies and depositional environments of early Mesozoic Newark Supergroup basins, eastern North America. Palaeogeogr. Palaeoclimatol. Palaeoecol., 84: 369-423.

Smoot, J.P. and Olsen, P.E., 1988. Massive mudstones in basin analysis and paleoclimatic interpretation of the Newark Supergroup. In: W. Manspeizer (Editor), Triassic-Jurassic Rifting and the Opening of the Atlantic Ocean. Elsevier, Amsterdam, pp. 249-274.

Smoot, J.P. and Olsen, P.E., 1994. Climatic cycles as sedimentary controls of rift basin lacustrine deposits in the early Mesozoic Newark basin based on continuous core. In: T. Lomando and M. Harris (Editors), Lacustrine Depositional Systems. SEPM Core Workshop Notes, 19: 201-237.

Sonnet, C.P., Finney, S.A. and Williams, C.R., 1988. The lunar orbit in the later Precambrian and the Elatina sandstone laminac. Nature, 335: 806-808. 
Street-Perrott, F.A., Mtchell, J.F.B., Marchand, D.S. and Brunner, J.S., 1995. Milankovitch and albedo forcing of the tropical monsoons: A comparison of geological evidence and numerical simulations for 9,000 yr BP. Philos. Trans. R. Soc. Edinburgh (Earth Sci.), in press.

Sutter, J.F., 1988. Innovative approaches to dating igneous events in the early Mesozoic basins of the eastern United States. U.S. Geol. Surv. Bull., 1776: 194-200.

Thomson, D.J., 1990a. Times series analysis of Holocene climate data. Philos. Trans. R. Soc. London Ser. A, 330: $601-616$.

Thomson, D.J., 1990b. Quadratic-inverse spectrum estimates: applications to palaeoclimatology. Philos. Trans. R. Soc. London, Ser. A, 332: 539-597.

Van Houten, F.B., 1962. Cyclic sedimentation and the origin of analcime-rich upper Triassic Lockatong Formation, westcentral New Jersey and adjacent Pennsylvania. Am. J. Sci., 260: $561-576$.

Van Houten, F.B., 1964. Cyclic lacustrine sedimentation, Upper Triassic Lockatong Formation, central New Jersey and adjacent Pennsylvania. In: O.F. Mermaid (Editor), Symposium on Cyclic Sedimentation. Kans. Geol. Surv. Bull., 169: 497-531.

Van Houten, F.B., 1969. Late Triassic Newark Group, northcentral New Jersey and adjacent Pennsylvania and New
York. In: S. Subitzki (Editor), Geology of Selected Areas in New Jersey and Eastern Pennsylvania and Guidebook of Excursions, New Brunswick, New Jersey (Geological Society of America, Field Trip 4). Rutgers Univ. Press, Atlantic City, NJ, pp. 314-347.

Walker, J.C.G. and Zahnle, K.J., 1986. Lunar nodal tide and distance to the Moon during the Precambrian. Nature, 330: 600-602.

Webb, J.A., 1981. A radiometric time scale of the Triassic. J. Geol. Soc. Aust., 28: 107-121.

Webster, P.J., 1985. The elementary monsoon. In: J.S. Fein and P.L. Stephens (Editors), Monsoons. Wiley, New York, pp. 3-32.

Williams, G.E., 1991. Upper Proterozoic tidal rythmites, South Australia: Sedimentary features, deposition and implications for the Earth's paleorotation. In: D.G. Smith et al. (Editors), Clastic Tidal Sedimentology. Can. Soc. Pet. Geol. Mem., 16: $161-178$.

Witte, W.K., Kent, D.V. and Olsen, P.E., 1991. Magnetostratigraphy and paleomagnetic poles from Late Triassic-earliest Jurassic strata of the Newark basin. Geol. Soc. Am. Bull., 103: 1648-1662.

Yan, Z. and Petit-Maire, N., 1994. The last $140 \mathrm{ka}$ in the afroasian arid/semi-arid transitional zone. Palaeogeogr. Palaeoclimatol. Palaeoecol., 110: 217-233. 